\title{
A(a)LS: Ammonia-induced amyotrophic lateral sclerosis
}

\section{[version 1; peer review: 2 approved, 1 not approved]}

\section{Bhavin Parekh}

Department of Biomedical Science, University of Sheffield, Sheffield, S10 2TN, UK

\author{
V1 First published: 14 May 2015, 4:119 \\ https://doi.org/10.12688/f1000research.6364.1 \\ Latest published: 14 May 2015, 4:119 \\ https://doi.org/10.12688/f1000research.6364.1
}

Open Peer Review

\begin{tabular}{|c|c|c|c|}
\hline \multicolumn{4}{|c|}{ Approval Status $\checkmark \backslash$} \\
\hline & 1 & 2 & 3 \\
\hline version 1 & $\checkmark$ & $\checkmark$ & X \\
\hline 14 May 2015 & view & view & view \\
\hline
\end{tabular}

1. Viswanathan Krishnan, University of California Davis School of Medicine, Davis, USA

Joy Goto, California State University, Fresno, USA

2. Smita Saxena, University of Bern, Bern, Switzerland

3. Scott T Brady, University of Illinois at Chicago, Chicago, USA

Any reports and responses or comments on the article can be found at the end of the article.

This article is included in the Rare diseases

collection. 
Corresponding author: Bhavin Parekh (bp2580@gmail.com)

Competing interests: No competing interests were disclosed.

Grant information: The author(s) declared that no grants were involved in supporting this work.

Copyright: $₫ 2015$ Parekh B. This is an open access article distributed under the terms of the Creative Commons Attribution License, which permits unrestricted use, distribution, and reproduction in any medium, provided the original work is properly cited. Data associated with the article are available under the terms of the Creative Commons Zero "No rights reserved" data waiver (CC0 1.0 Public domain dedication).

How to cite this article: Parekh B. A(a)LS: Ammonia-induced amyotrophic lateral sclerosis [version 1; peer review: 2 approved, 1 not approved] F1000Research 2015, 4:119 https://doi.org/10.12688/f1000research.6364.1

First published: 14 May 2015, 4:119 https://doi.org/10.12688/f1000research.6364.1 


\section{Introduction}

Amyotrophic lateral sclerosis (ALS) is the most feared, frequent, flummoxing and fatal motor neuron disease ${ }^{1-3}$. It is a biphasic disease which starts insidiously, later followed by relentless progression once symptomatic ${ }^{4}$. Although rare, it is a grim and demeaning illness: it slowly cripples and confines its victims in their own body, ultimately killing them by breathing failure within $3-5$ years after onset $^{2,5}$. No cure exists ${ }^{1}$. Ever since Charcot's description of ALS (1869), a classical view defines ALS as an adult-onset neurodegenerative disease of upper and lower motor neurons ${ }^{6,7}$. However, ALS is clinically characterised by variability about the type and degree of motor neuron and non-motor neuron involvement ${ }^{8}$.

ALS pathology involves an interaction of multiple genes and environmental factors. Indeed, ALS is mainly a polygenic disease (70\%-90); and the heritable form (familial ALS) contributes to merely $30 \%$ of total ALS cases ${ }^{3,9}$. Remarkably, mutant C9ORF72, TARDBP, FUS, and SOD1 genes account for $70 \%$ of all familial ALS cases ${ }^{10}$. Evidence shows that environmental factors such as intense physical activity, cigarette smoking, viral infections, and the ingestion of non-protein amino acids (i.e. $\beta$ - $\mathrm{N}$-methylaminoL-alanine) play a role in $\mathrm{ALS}^{5,11,12}$.

\section{ALS aetiology: an enduring enigma}

Despite nearly 150 years of research, ALS remains an enigma ${ }^{13}$, although, at the cellular, molecular and metabolic levels, a staggering and ever expanding list of pathogenic mechanisms have been linked to $\mathrm{ALS}^{13,14}$. These include protein aggregation, mitochondrial dysfunction, oxidative/nitrosative stress, endoplasmic reticulum (ER) stress, axonal transport defects, glutamate excitotoxicity, impaired macroautophagy, impaired glycolysis, neuroinflammation, and glucose and fat metabolism impairments ${ }^{13-19}$. However, hitherto no hypothesis exist that effectively links all these mechanisms to a singular central cause ${ }^{3}$. Hence, despite steadily accumulating knowledge about ALS, a key question still lingers: what cause ALS?

\section{ALS: a multi organ disease}

Since ALS is manifestly a neurological disorder, researchers have long embraced an intuitive neurocentric view of ALS, assuming that intrinsic neuronal pathology causes $\operatorname{ALS}^{7,20}$. Against this view, however, growing evidence suggests that ALS pathology extends well beyond neuronal cells and involves multiple organs ${ }^{7,14,21}$. Unsurprisingly, ALS is now deemed as a systems disease ${ }^{20,22}$. Not only that, evidence increasingly shows that primary pathological events, inherited or acquired, within these organs may act as distal cause of ALS $^{14,21,22}$. Such evidence is reviewed below.

\section{Role of skeletal muscle}

ALS starts and spreads from skeletal muscle ${ }^{14,23}$. Indeed, some early symptoms of ALS involve the neuromuscular system: muscle atrophy, cachexia (wasting), weakness, and fasciculation (twitches) $)^{7,11,14,19,23}$. In fact, cachexia reduces survival of ALS patients ${ }^{19}$. Reinforcing such observations, data from animal models of ALS showed neuromuscular dysfunction precede motor neurons loss ${ }^{14}$. For instance, Frey et al. showed selective loss of fast-fatigable neuromuscular synapses of SOD1G93A mice by 6 weeks of age, 2 month before symptomatic phase ${ }^{24}$. Cogently, a study showed that the expression of mutant gene (SOD1G93A) exclusively in skeletal muscle of transgenic mice caused cachexia, neuromuscular denervation, paresis, and motor neuron degeneration ${ }^{25}$.

Skeletal muscle possesses mainly two types of muscle fibres: fast twitch and slow twitch ${ }^{26}$. Lately, evidence suggests that in ALS fast twitch muscle motor units are selectively damaged before overt symptoms, whereas slow twitch motor units show damage after overt symptoms ${ }^{27,28}$. For example, a set of studies showed a rapid motor unit loss during the presymptomatic phase (5 weeks of age) in fast but not slow-twitch muscles of the SOD1G93A mouse ${ }^{27}$. Accordingly, fast twitch muscle appears to be more susceptible to damage in ALS patients ${ }^{28}$. Therefore, fast twitch muscle pathology appears to be the distal cause of ALS.

Together, those findings have led to the "dying-back" hypothesis ${ }^{14}$. This holds that ALS is a distal axonopathy in which pathological changes first arise distally at the neuromuscular junction and progress backward toward the spinal cord cell body ${ }^{14}$. That said, however, recent and prior research mandates refinement of this hypothesis. Recently, experiments in the SOD1G93A mice showed independent and parallel degeneration of both upper and lower motor neurons at early stage, hinting at a common pathological mechanism ${ }^{29}$. Consistent with this, recent neuroimaging studies showed early stage involvement of upper motor neuron (UMN) in ALS patients ${ }^{30}$. In fact, Gower (1886), Charcot's contemporary, suggested simultaneous and independent degeneration of upper and lower motor neurons in ALS ${ }^{31}$. Thus, a common but hitherto unidentified pathological factor emanating from skeletal muscle appears to damages both upper and lower motor neurons.

\section{Liver: an emerging locus of ALS}

Aside from skeletal muscle, mounting evidence suggests that liver dysfunction commonly occurs in ALS. Indeed, literature on the liver pathology in ALS has existed for over a half century $^{32,33}$. Earlier, researchers showed a range of liver abnormalities in ALS patients including the disturbance of unconjugated bilirubin metabolism, mitochondrial defects, and copper accumulation in hepatic lysosomes ${ }^{32}$. More recently, clinical studies suggest that hepatic steatosis (fatty liver degeneration) is a common and unique phenomenon in motor neuron diseases including $\operatorname{ALS}^{22,34,35}$. Nodera et al. found that hepatic steatosis was present in $76 \%$ of ALS patients ${ }^{22}$. In line with this, studies showed reduced growth hormone/insulin-like growth factor-1 (GH/IGF-I) levels, which induce hepatic steatosis, in $\mathrm{ALS}^{21,36}$. In keeping with this, hyperhomocysteinemia, which is associated with hepatic fat accumulation, commonly occurs in ALS patients ${ }^{37,38}$. Moreover, research showed that ALS-associated environmental factors such as virus infection (i.e. retrovirus virus and HIV) and cigarette smoking cause hepatic steatosis ${ }^{5,12,39,40}$. Furthermore, viral hepatitis, which causes hepatic insufficiency and frequent fatty liver degeneration, has been linked to motor neuron disease ${ }^{41-44}$. Finally, Reye-like syndrome, associated with fatty liver degeneration, has been associated with spinal muscular atrophy (SMA), a lower motor neuron disease ${ }^{35}$.

A number of genetic findings also support this notion. Iron dysregulation disorders such as HFE gene-related hemochromatosis and hyperferritinemia, which induces hepatic steatosis, frequently 
(30\%) occurs in ALS ${ }^{45,46}$. Additionally, mutant cholesterol and lipid pathways genes such as TDP-43 ATXN2, paraoxonase and CYP7A1, implicated in hepatic steatosis, have been linked to $\mathrm{ALS}^{47-55}$. Moreover, an interaction between disturbances in hepatic mitochondrial function and ER homeostasis causes hepatic steatosis; and investigators discovered morphological changes in ER structure and mitochondria in the liver of ALS patients ${ }^{32,56}$. These findings support the evidence that mutant ER-stress regulating genes such as XBP1, SigR1, VCP, TDP-43, FUS, SOD1, and VAPB are linked to $\mathrm{ALS}^{57,58}$. Furthermore, SMN gene, implicated in ALS and SMA, have been shown to regulate the development and function of liver ${ }^{35}$.

Finally, hepatic steatosisis is linked to the metabolic syndrome, characterised by hyperglycaemia, hyperglucagonemia, insulin resistance and altered serum triglycerides; and such findings have been reported in $\mathrm{ALS}^{5-65}$. In this regard, it is interesting to note that damage to fast twitch skeletal muscle, the main site of glucose disposal and the largest reservoir of glycogen in humans, leads to hepatic steatosis ${ }^{66}$.

Notably, Li et al. showed exendin-4, which counteracts hepatic steatosis, ameliorated motor neuron degeneration partly by correcting this systemic metabolic alteration ${ }^{67,68}$. This clearly suggests that, much like skeletal muscle, liver pathology is not merely an innocent bystander, but rather a premorbid condition, which plays an active role in ALS pathogenesis.

\section{Aims}

Thus, (i) identifying skeletal-muscle produced unknown pathological factor, (ii) unravelling its nexus and synergism with hepatic steatosis, (iii) understanding the mechanisms by which this pathology factor causes motor neuron damage, and (iv) revealing the cause(s) of clinical heterogeneities would fully untie the Gordian knot of ALS pathology, allowing the development of predictive and prognostic biomarkers as well as potent drugs ${ }^{3,13}$. Hence, by taking a systems view, this paper aims to fill these knowledge gaps. Moreover, by fusing these separate pieces together, this paper presents a full picture of ALS pathology.

\section{Impaired glycolysis in fast twitch muscle: one of the pathological triggers of ALS}

Evidence suggests that defective energy deficit in skeletal muscle triggers ALS. Investigators found impaired skeletal muscle metabolism, characterised by low ATP levels and hypermetabolism, causes neuromuscular dysfunction in ALS mouse model ${ }^{69,70}$. Conversely, metabolic interventions such as high-calorie diets and reducing hypermetabolism improved survival and alleviated symptoms in $\mathrm{ALS}^{19,70}$. However, the functional link between skeletal muscle metabolic impairment and ALS remains nebulous. Instructively, since ALS begins from fast twitch muscle, which relies on anaerobic glycolysis for energy (i.e., ATP), this immediately suggests that impaired anaerobic glycolysis produces the unknown pathological trigger.

\section{Impaired glycolysis in ALS}

Compelling evidence suggests that muscle glycolysis is impaired in ALS. Valosin-containing protein (VCP), a gene linked to ALS, causes defective muscle glycolysis and reduced ATP levels. Dupis et al. linked upregulation of mitochondrial uncoupling proteins UCP1 and UCP3 - which suppresses glycolysis and causes hypermetabolismto muscle denervation in $\mathrm{ALS}^{71}$. Bernardini et al. showed low expression of glycolysis genes such as FBP2 and enolase 3 in the skeletal muscles of ALS patients ${ }^{72}$. Brockington et al. uncovered down regulation of glycolytic enzyme lactate dehydrogenase 1 in the $\mathrm{VEGF}^{\delta / \delta}$ mouse model of $\mathrm{ALS}^{73}$. Moreover, experiments showed that the gain-of-interaction of the SOD1G93A mutant with cytosolic malate dehydrogenase induces glycolytic impairments ${ }^{74}$. Dunckley et al. linked variants of FLJ10986, a protein linked to glycolysis, with the susceptibility of sporadic ALS ${ }^{75}$. Collectively, these findings clearly show impaired glycolysis in skeletal muscle of ALS patients and mouse model.

\section{Impaired muscle glycogen and glucose homeostasis in ALS}

Notably, fast twitch skeletal muscle glycolysis depends on muscle glycogen storage and glucose transporter 4 (GLUT4)-mediated muscle glucose uptake ${ }^{26,76}$. Accumulating evidence suggests defective muscular glycogen metabolism and impaired GLUT4-mediated muscular glucose uptake in ALS. Derave et al. discovered diminished muscle ATP and glycogen accumulations in SOD1 G93A mice $^{27}$. Smittkamp et al. revealed impaired insulin-stimulated glucose uptake exclusively in fast twitch skeletal muscle in middlestage SOD1 G93A mice ${ }^{77}$. Accordingly, fast twitch skeletal muscle fibres of TDP-43 transgenic mice show defective insulin-induced GLUT4 translocation and glucose uptake ${ }^{77}$. Moreover, in the mutant TDP-43-linked ALS mice, Perera et al. reported decreased AMPK, which mediates muscle contraction-induced glucose entry and glycogen synthesis ${ }^{76,78,79}$. Conversely, AMPK activator drugs (i.e. latrepirdin) delayed ALS in SOD1G93A mice ${ }^{80}$. Furthermore, muscle contraction facilitated glucose uptake involving $\mathrm{Ca} 2+/$ calmodulindependent GLUT4 translocation appears to be defective in ALS. For example, investigators linked mutant neuregulin-ERBB4 gene, involved in calcium-induced glucose uptake during muscle contraction, to $\mathrm{ALS}^{79,81}$. Thus, it is obvious that ALS involves impaired carbohydrate metabolism that supports muscle glycolysis.

\section{ALS resistance of extraocular muscles (EOMs): role of glycolysis}

Finally, the metabolic characteristics of-ALS-resistant—extraocular muscles (EOMs) further consolidate this notion ${ }^{82}$. Two fundamental differences exist between EOMs and skeletal muscle metabolism ${ }^{83}$. First, compared to skeletal muscles, EOMs have high glycolysis capacity, evident by the overexpression of glycolytic enzymes (e.g. lactate dehydrogenase, enolase $)^{83}$. Second, owing to their high vascularity, EOMs rely more on instantaneous glucose uptake-less on glycogen storage and GLUT4-mediated muscle glucose uptake ${ }^{83}$. All in all, these three sets of findings point that defective glycolysis causes ATP deficits in fast twitch skeletal muscle of ALS patients. Hence, the unknown pathological factor emanating from skeletal muscle appears to have direct connection with defective muscle glycolysis. How?

\section{Ammonia: the elusive pathological factor}

Notably, defective glycolysis, which reduces ATP levels, in fast twitch skeletal muscle activates catabolic reactions of adenine nucleotides 
(i.e. purine nucleotide cycle) and amino acids (Figure 1$)^{84,85}$. Intriguingly, such catabolic reactions produce ammonia-a neurotoxin 1000 times more toxic than ethanol at equimolar concentrations ${ }^{85,86}$. Since ammonia is toxic, it is obligatorily removed mainly through hepatic urea cycle which transforms ammonia into urea ${ }^{87}$. Notably, when the urea cycle is impaired, as it occurs in fatty liver disease, increased ammonia production from skeletal muscle or from dietary sources can cause chronic hyperammonia $(>35-50 \mu \mathrm{M})$ and consequent neurodegeneration and motor impairments (Figure 1 and Figure 2) ${ }^{33,88-92}$. Indeed, in many liver diseases, including fatty liver disease which commonly occurs in ALS, because of impaired urea cycle-mediated ammonia removal, hyperammonia frequently leads to corticospinal hyperexcitability, myelopathy and spasticityfeatures strikingly reminiscent of neurophysiological phenotypes of ALS symptoms ${ }^{93-97}$.
Ammonia neurotoxicity: hypothesis and evidence

Together, these findings provide a compelling rationale for a new hypothesis. ALS pathology might involve not only skeletal muscle-induced increased ammonia production, because of impaired glycolysis, but also impair ammonia removal, secondary to hepatic steatosis-induced faulty urea cycle, leading to chronic hyperammonia and consequent progressive motor neuron degeneration (Figure 1 and Figure 2). Astonishingly ammonia's role has seldom been directly investigated. Nonetheless, diverse data obtained from clinical and animal studies support this hypothesis showing that hyperammonia increases ammoniagenesis and decreases ammonia removal in ALS.

A clinical study showed elevated ammonia level in motor neuron disease patients-with ammonia levels inversely correlated to

\section{Imbalanced interorgan ammonia metabolism}

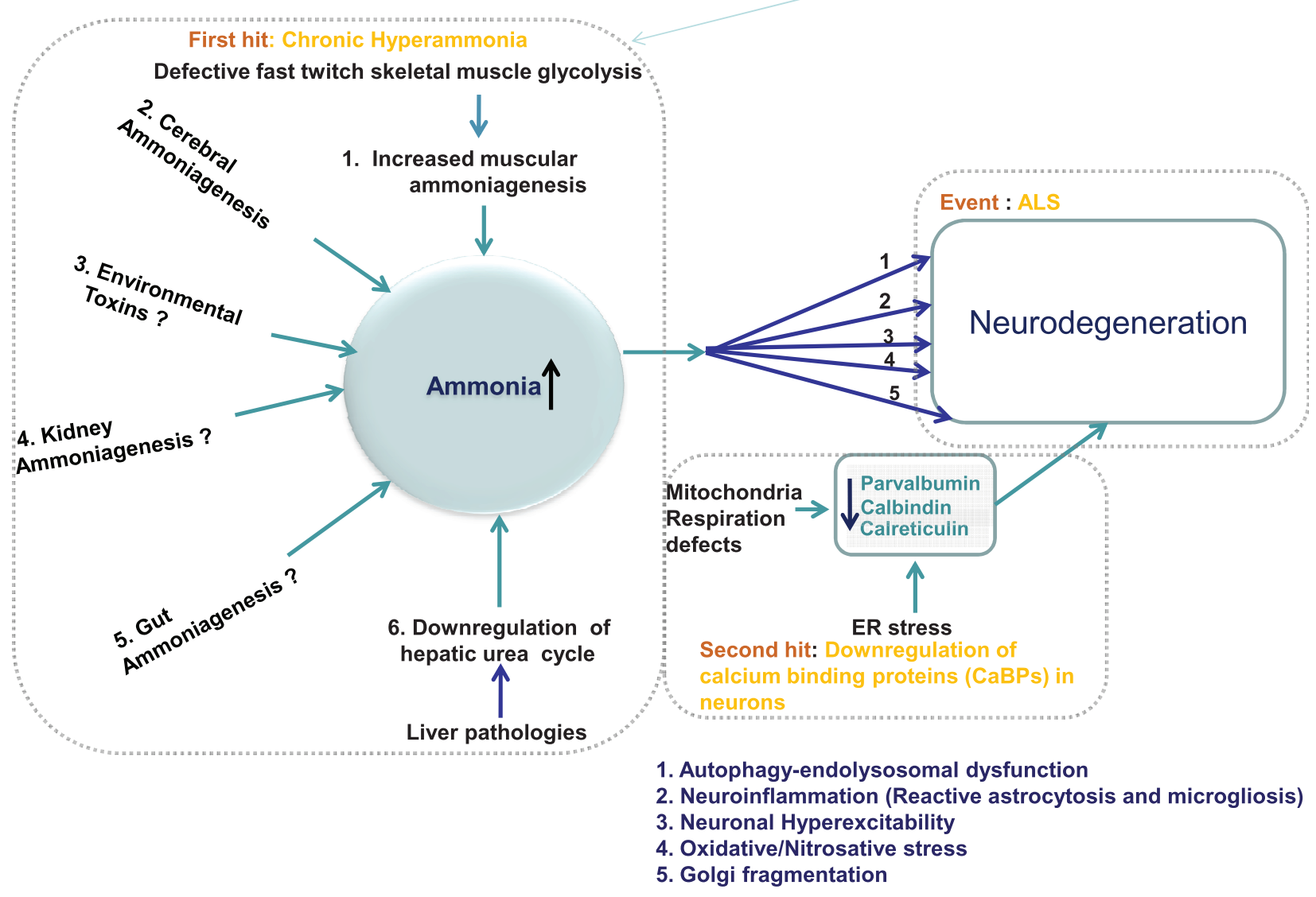

Figure 1. Line diagram: mechanisms of motor neuron damage in ALS. Mechanism of motor neuron degeneration in ALS involves two main factors: (i) ammonia neurotoxicity and (ii) down regulation of neuronal calcium binding proteins (CaBPs). Owing to imbalanced interorgan ammonia metabolism, ammonia, a well-known neurotoxin, accumulates in neurons. Among the five organs (brain, skeletal muscle, gut, liver and kidney) involved in ammonia metabolism, ALS appears to mainly involve the role of liver and skeletal muscle in that confluence of impaired ammonia removal—owing to impaired hepatic urea cycle—and increased muscular ammoniagenesis—owing to impaired glycolysis in fast twitch skeletal muscle-lead to chronic hyperammonia in ALS. In the brain, ammonia activates several neurodegenerative pathways such as (1) autophagy-endolysosomal dysfunction (2) neuroinflammation (3) oxidative stress (4) Golgi fragmentation and (5) neuronal hyperexcitability. In the absence of neuronal calcium binding proteins (CaBPs) such as parvalbumin, calbindin, calreticulin, activation of these degenerative pathways lead to motor neuron damage. Notably, decrease in calreticulin, because of increased ER stress, leads to lower motor neuron damage, whereas the down-regulation of parvalbumin and calbindin, because of defective mitochondrial respiration, leads to upper motor neuron damage. 


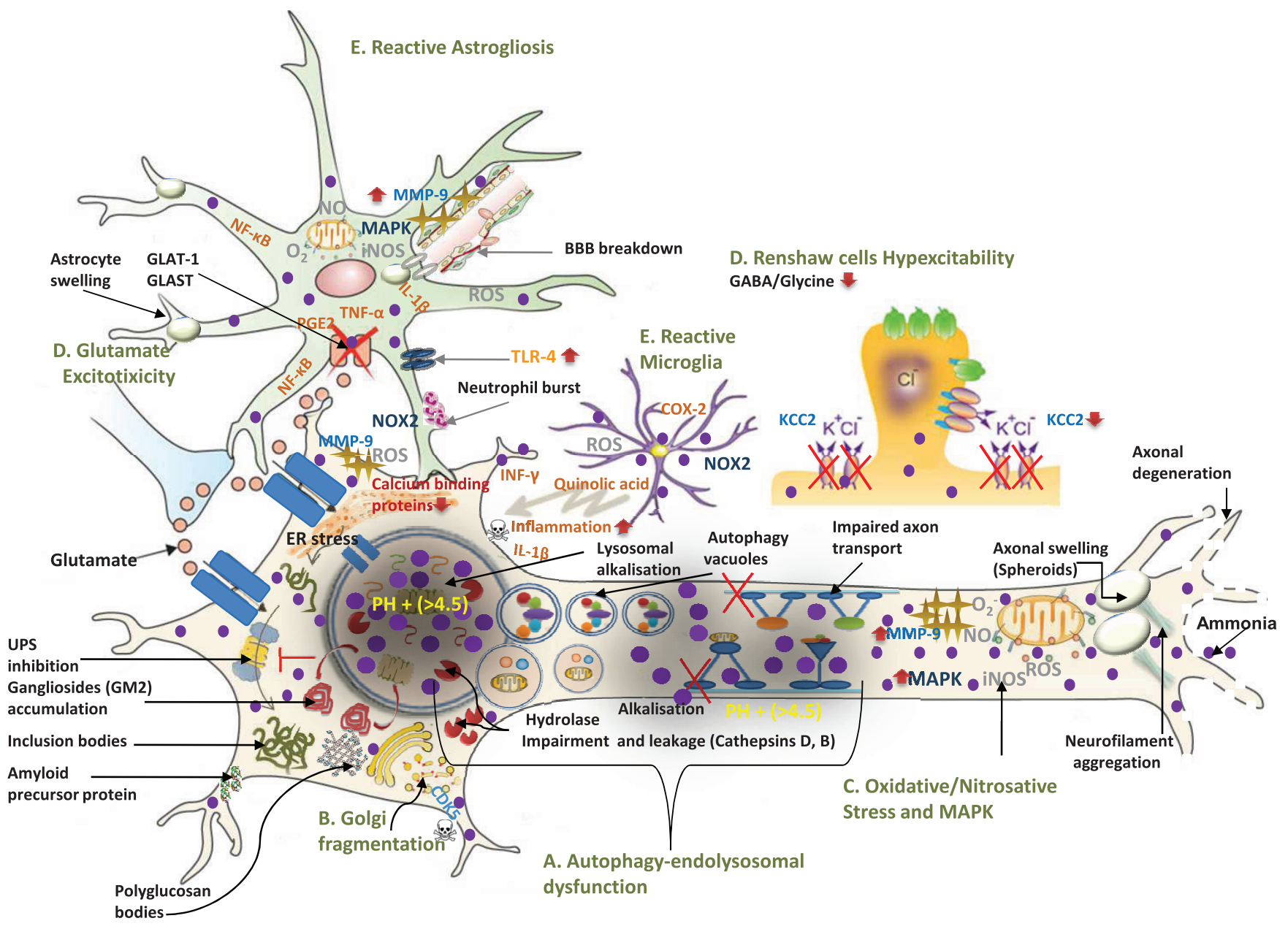

Figure 2. A molecular model of ammonia-induced motor neuron degeneration in ALS. (Modified with permission from 232). Ammonia intoxication directly damages motor neurons through five mutifactorial pathological mechanisms: 1) alkalisation-induced impairment of macroautophagy-endolysosomal system, 2) Golgi impairment, 3) increased oxidative/nitrosative stress and MAPK up-regulation 4) neuronal hyperexcitability and 5) neuroinflammation. These mechanisms explain frequently found cellular, molecular and neurophysiological phenotypes of motor neuron damage in ALS. A. Owing to ammonia-induced alkalisation, impairment of macroautophagy-endolysosomal system induces several key molecular histopathological features of ALS including : (i) ubiquitinated (Lewy and skein body-like inclusions) and non-ubiquitinated inclusion bodies (i.e. bunia bodies) formation, (ii) amyloid precursor protein (APP), (iii) gangliosides accumulation (i.e. GM2), (iv) autophagy vacuoles, (v) neurofilament aggregation and axonal swelling. B. Ammonia activates CDK5 which in turn leads to frequently observed Golgi fragmentation. C. Ammonia-induced oxidative/nitrosative stress and MAPK-up-regulation lead to multiple cellular and molecular pathological features such as: (i) blood brain barrier (BBB) breakdown, and (ii) MMP-9-induced ER stress. D. Ammonia causes neuronal hyperexcitability by (i) down-regulating astrocyte glutamate transporters (GLAT-1 and GLAST) and (ii) lowering potassium-chloride co-transporter KCC2 level which suppresses GABA and Glycine-mediated inhibitory neurotransmission. E. Ammonia leads to neuroinflammation secondary to reactive microglial and astrogliosis. This occurs because of (i) quinolic acid release from microglia (ii) up-regulation of pro-inflammatory cytokines (TNF, IL-1 $\beta, N F-\kappa B$, and PGE2) in astrocytes (iii) TLR-4 activation and (iv) neutrophil burst derived NADPH oxidase (NOX)-induced oxidative stress.

disease duration ${ }^{98}$. These investigators also found a causal relationship between ammonia and ALS by noting that infusion of amino acids, which causes ammoniagenesis, aggravates ALS ${ }^{98}$. Moreover, dietary supplements of branched chain amino acids was one of the factors associated with the early onset of ALS (45 years) in Italian soccer players $^{99}$. Accordingly, other investigators reported accelerated skeletal muscle protein catabolism ALS $^{100}$. This chimes with the fact that hepatic steatosis-induced glucagon secretion, which occurs in ALS, increases ammoniagenesis through protein degradation $^{101,102}$. Consistent with this, as noted above, intense or prolonged physical exertion, an ammoniogenic activity, is an ALS risk factor ${ }^{11,103}$.

Beside a link between hepatic steatosis and a faulty urea cycle, other lines of clinical evidence further implicate the impaired urea cycle in $\mathrm{ALS}^{48,91,104}$. For example, Iłzecka et al. showed decreased arginine levels, an amino acid required for liver urea cycle function, in ALS patients ${ }^{105}$. Additionally, research showed that metabolic acidosis, which impairs urea cycle, occurs in ALS ${ }^{60,106}$. Impaired hepatic urea cycle activates glutamine synthetase, an alternative 
ammonia detoxification pathway, and researcher also found increase in glutamine synthetase expression in blood platelets of ALS patients ${ }^{107,108}$.

Animal models of ALS further cement this ammonia hypothesis. Investigators showed hyperammonia and impaired urea cycle in 50 day old SOD1G93A mice compared to wild type mice of the same age $^{109}$. Moreover, these investigators showed increased glutamine, a precursor of ammonia, in SOD1G93A mice ${ }^{109}$. Additionally, in the mutant SOD 1 G86R mice, de Aguilar et al. showed early (3 months of age) muscle denervation along with increased AMP deaminase-3 (AMPD3), an enzyme of purine nucleotide cycle involved in ammoniagenesis ${ }^{110}$. Furthermore, a set of studies showed increased arginine vasopressin release in the SOD1 mice, and independent research showed that arginine vasopressin causes muscle protein degradation and consequent ammoniagenesis ${ }^{11,112}$. Conversely, research showed that ammonia-counteracting compounds such as phenylbutyrate, ariginine, resveratrol and l-carnitine alleviated symptoms and enhanced survival in the ALS mouse model ${ }^{97,113-118}$.

Further supporting this hypothesis, experiments have shown that environmental neurotoxins implicated in ALS causes ammonia toxicity. Dietary intake of $\beta$-N-methylamino-L-alanine, a non-protein amino acid linked to Guam's ALS-PDS complex epidemic, causes liver damage and ammonia toxicity ${ }^{119,120}$. Similarly, the ingestion of Lathyrus sativus seeds, implicated in neurolathyrism (an upper motor neuron disease), causes liver dysfunction, urea cycle impairment, and chronic ammonia toxicity ${ }^{121,122}$. Finally, animal studies showed that the pesticide pyrethroid, which causes an ALS-mimicking syndrome, leads to protein catabolism ammonia toxicity ${ }^{123,124}$.

Yet another line of evidence bolsters the ammonia neurotoxicity hypothesis. Interestingly, reports showed that motor neuron disease could be one of Huntington's disease (HD)'s presenting features ${ }^{125,126}$. In fact, aside from genetic overlap with ALS, HD shares many pathophysiological characteristics with ALS: skeletal muscle atrophy, hepatic steatosis, hyperglycaemia and adipose tissue dysfunction ${ }^{127,128}$. Tellingly, although often regarded as curious findings rather than telltale observation, impaired urea cycle as well as hyperammonia occur in $\mathrm{HD}^{127}$. Strikingly, data from mouse models of HD showed that protein-restricted diets not only reduced hyperammonia but also prevented the motor deterioration ${ }^{90}$. This suggests that ammonia could be a common culprit in range of neurodegenerative conditions, especially affecting motor system.

In addition to muscles and the liver, ammonia metabolism involves other organs, including the gut, the kidneys and the brain (Figure 1$)^{87,89}$. Hence, this hypothesis does not preclude a role of these organs. Although no evidence has yet emerged to implicate the gut and kidneys in ALS, some data at least suggest a role of cerebral ammoniagenesis in ALS. Studies showed increased deamination of catecholamine, which causes cerebral ammoniagenesis, in ALS, evident by the overactivity of catecholamine oxidising enzymes such as MAO-B and aldehyde oxidase ${ }^{89,129-131}$. Put together, these findings implicate ammonia neurotoxicty in ALS.

\section{Mechanisms of ammonia's neurotoxicity}

When hyperammonia occurs, ammonia enters into the brain, leading to neurotoxicity. Ammonia exerts pleiotropic neurotoxic effects by activating an array of cellular mechanisms, which are the proximal causes of ALS (Figure 1 and Figure 2). These mechanisms include: 1) alkalisation-induced impairment of macroautophagy-endolysosomal system, 2) Golgi impairment, 3) increased oxidative/nitrosative stress and mitogen-activated protein kinase (MAPK) up-regulation 4) neuronal hyperexcitability and 5) neuroinflammation ${ }^{89,132-136}$.

As described below, taken together, these five mechanisms not only explain several frequent cellular and molecular histopathological hallmarks of ALS but also neurophysiological features of ALS (Figure 1 and Figure 2). The cellular histological features, explained by ammonia's toxicity, include axon swelling, blood brain barrier breakdown and astrogliosis and microgliosis ${ }^{137-139}$. The molecular pathological features, explained by ammonia's toxicity, include formation of inclusion bodies such as bunia bodies and Lewy bodies, gangliosides accumulation, glycogen aggregation, neurofilament derangement, Golgi fragmentation, and reduced glutamate transporters ${ }^{60,140-145}$. Moreover, ammonia toxicity explains a key neurophysiological feature of ALS: neuronal hyperexcitability ${ }^{17}$. Finally and most importantly, ammonia toxicity explains why ALS is mainly a motor neuron disease.

\section{Alkalisation-induced impaired macroautophagy- endolysosomal system}

Ammonia-induced alkalisation impairs the macroautophagyendolysosomal system, one of the main cellular garbage disposal systems. This occurs at least in two ways. First, ammonia, a weak base, preferentially accumulates in lysosomes because of their low acidity $(\mathrm{PH} 4.5)^{134}$. Consequently, intra-lysosomal alkalisation and lysosomal enzyme leakages occur, impairing the lysosomal hydrolysis of proteins, lipids and carbohydrates (Figure 2) ${ }^{134}$. Second, ammonia alkalises acidic membranous compartments of axon terminals, jamming membrane microtubules and thereby blocking the anterograde-to-retrograde transport of endosomes ${ }^{146}$. Consequently, impaired fusion of endocytic compartments with lysosomes occurs, causing defective autophagy of endocytosed

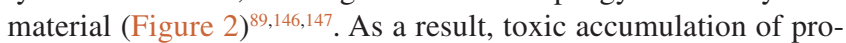
tein aggregates, glycolipids, and carbohydrates occurs ${ }^{89}$. In turn, these toxic by-products activate the apoptosis programme, causing cell death ${ }^{148}$.

Ammonia's alkalisation-induced toxicity is especially relevant to ALS because macroautophagy-endolysosomal dysfunction causes motor neuron degeneration ${ }^{149}$. Indeed, mutant genes of this pathway such as SOD1, FIG4, CHMP2B, SQSTM1, DCTN1, DYNC1H1, and RAB7A have been linked to ALS $^{149}$. Consistent with this interpretation, research showed impaired dynein-dependent retrograde axonal transport, required for autophagosome-lysosome fusion, causes motor neuron degeneration ${ }^{150,151}$. Furthermore, consistent with lysosomal enzyme leakage, investigators reported increased lysosomal enzyme levels (i.e. acid phosphatase, Cystatin C) in the cerebrospinal fluid (CSF) and plasma of ALS patients ${ }^{152,153}$. 


\section{Impaired lysosomal proteolysis}

Ammonia-induced impaired lysosomal proteolysis explains key histopathological hallmarks of ALS including formation of inclusion bodies (Figure 2). Ammonia-induced alkalinisation in lysosomes impairs the activities of protease enzymes including cathepsin B and cathepsin $\mathrm{D}^{134,154}$. Strikingly, investigators showed downregulation of cathepsin B and cathepsin D in ALS ${ }^{155,156}$. Notably, defective lysosomal proteolysis causes swollen axonal dystrophy (spheroids), with histological features such as ubiquitinated and non-ubiquitinated inclusion bodies, amyloid precursor protein, and neurofilament aggregation ${ }^{157}$. In keeping with this, research revealed such findings in $\operatorname{ALS}^{144,145,156,158-161}$.

In regard to non-ubiquitinated inclusion bodies, Kikuchi et al. showed that decreased cathepsin B generates Bunina bodies (small eosinophilic intraneuronal lysosomal inclusion bodies) in motor neurons, a hallmark of ALS (Figure 2) ${ }^{140,156}$. Since cathepsin D mediates lipofuscin and $\alpha$-synuclein clearance, and since downregulation of cathepsin D occurs in ALS, this explains frequently observed deposits of lipofuscin granules and $\alpha$-synuclein aggregation in ALS patients ${ }^{148,162-164}$. Moreover, reduced cathepsin B activity induces amyloid precursor protein (APP) accumulation, and Bryson et al. showed increased APP level in the SOD1 G93A mouse, which contributed to motor neuron damage ${ }^{158,165}$. As for impaired proteolysis-induced ubiquitinated inclusion bodies, ubiquitin inclusion aggregates such as Lewy body-like inclusions' and 'skein-like inclusions' have been found in ALS (Figure 2) ${ }^{145,166}$. This finding accords with the observations that inhibition of macroautophagy impairs the ubiquitin proteasome system (UPS) ${ }^{167}$. Finally, neurofilament aggregation and spheroid formations have been found in the ALS mouse model and in patients (Figure 2) ${ }^{161}$.

\section{Impaired lysosomal ganglioside clearance}

Gangliosides are complex sialylated glycosphingolipids, particularly found in the $\mathrm{CNS}^{168}$. Notably, GM2 ganglioside is a main ganglioside in motor neurons ${ }^{169}$. Accumulation of GM2 ganglioside, owing to impaired lysosomal Hexosaminidase (Hex) enzymes, frequently causes motor neuron disease ${ }^{170-172}$. For example, Banerjee et al. reported slow accumulation of GM2 ganglioside, primarily in motor neurons, in patients with progressive motor neuron disease associated with partial Hex A and no Hex B activity ${ }^{172}$. By implication, this suggests that accumulation of gangliosides including that of GM2 occurs in ALS and that ammonia increases GM2 ganglioside levels. Indeed, although scantly investigated, some investigators reported increased ganglioside levels in ALS including GM2 ganglioside ${ }^{142,173,174}$. In line with ammonia's role in ganglioside metabolism, Perez et al. showed that ammonia causes leakage of Hexosaminidase A (Hex A), indicating GM2 accumulation ${ }^{175,176}$. Thus, ammonia-induced GM2 accumulation could partly explains the heightened vulnerability of motor neurons in ALS (Figure 2).

\section{Impaired lysosomal carbohydrate clearance}

Animal and clinical studies reported neuronal and glial glycogen accumulation and polyglucosan bodies (branched chained glycogen aggregates) in ALS (Figure 2) 60,177,178. Notably, Dodge et al. showed that decreased level of $\alpha$-glucosidase - a glycogen degrading lysosomal enzyme-partly causes glial and neuronal glycogen accumulation in ALS, and experiments showed that ammonia leaks $\alpha$-glucosidase from lysosomes ${ }^{60,179}$. Thus, ammonia-mediated lysosomal dysfunction explains yet another histological feature of ALS. Of note, this fits with the observations that upper and lower motor neuron lesions frequently arise in polyglucosan body diseases ${ }^{180}$.

\section{Impaired Golgi function}

Ammonia toxicity could explain Golgi apparatus fragmentation in ALS, an early and frequently observed event ${ }^{141}$. Sun et al. showed that CDK5 activation fragments Golgi apparatus ${ }^{181}$. Interestingly, Cagnon and Braissant showed that ammonia activates CDK5. They also showed that CDK5 activation led to neuronal cell death and impairment of axonal outgrowth ${ }^{135}$. Apparently, p25-induced mislocalization and deregulation of CDK5 activity occurs in ALS (Figure 2) ${ }^{143,182}$. In fact, Nguyen et al. reported that an attempted re-entry of motor neurons into the G1-S phase of the cell cycle subsequent to CDK5 deregulation is a critical step of neurodegeneration in $\mathrm{ALS}^{182}$.

\section{Increased oxidative/nitrosative stress and MAPK expression}

Additionally, data suggested that ammonia induces oxidative/ nitrosative stress and MAPK expression, frequently found pathological features of ALS (Figure 2) ${ }^{132}$. Research showed that oxidative/nitrosative stress and MAPK increases extracellular matrix degrading enzymes such as urokinase-type plasminogen activators and MMP-9 ${ }^{183}$. Unsurprisingly, experiments found that increased levels of these extracellular matrix degrading enzymes occur in ALS $^{184}$. Strikingly, Kaplan et al. observed overexpression of MMP-9 increased the vulnerability of fast fatigable limb-innervating motor neuron ${ }^{185}$. MMP-9 appears to exert neurotoxicity mainly through up-regulation of ER stress (Figure 2) ${ }^{185}$. Moreover, Skowrońska et al. showed that increase in MMP-9, which degrades the extracellular matrix, destroys the blood brain barrier (BBB) ${ }^{186}$. Predictably, Nicaise et al. showed impaired blood-brain and blood-spinal cord barriers in mutant SOD1-linked ALS rodents ${ }^{138}$. Additionally, since MAPK regulates cytoskeletal homeostasis, ammonia-induced MAPK activation explains why cytoskeleton abnormalities such as intermediate filaments accumulation occur in $\operatorname{ALS}^{160,187}$.

\section{Neuronal hyperexcitability}

Furthermore ammonia intoxication explains neuronal hyperexcitability in ALS-a cardinal characteristic of $\mathrm{ALS}^{16}$. By decreasing potassium-chloride cotransporter $\mathrm{KCC} 2$, located in the brain and spinal cord, ammonia increases chloride levels in neurons (Figure 2) ${ }^{188}$. Increased neuronal chloride levels in turn suppress GABA and Glycine-mediated inhibitory neurotransmission, causing neuronal hyperexcitability (Figure 2) ${ }^{189}$. In keeping with this, Fuchs et al. discovered decreased KCC2 expression in ALS-vulnerable motoneurons in spinal cord and hypoglossal nuclei of SOD1-G93A mice but not in $\mathrm{EOMs}^{190}$. Concordantly, researchers reported spinal motor neuron hyperexcitability and degeneration in ALS patients ${ }^{191}$. In fact, Hübner et al. showed that KCC2 knockout mice died after birth owing to motor deficits that caused respiratory failure, a feature similar to $\mathrm{ALS}^{189}$.

Furthermore, ammonia causes glutamatergic excitotoxicty. By MAPK activation and increasing oxidative stress, ammonia decreases the glutamate transporter EAAT2 (GLT-1) and glutamate-aspartate transporter 
(GLAST) (EAAT-1) in astrocytes (Figure 2) ) $^{133,192}$. Consequently, decreased transporters impair astrocyte-mediated high affinity glutamate uptake and clearance, leading to defective glutamatergic neurotransmission and excitotoxicity ${ }^{133,192,193}$. In line with this, decreased GLT-1 and GLAST have been found in the spinal cord of SOD1 G93A mice and ALS patients ${ }^{194-196}$. Interestingly, increased CSF glutamate was associated with a spinal onset of the disease and with severity of the symptoms in $41 \%$ of ALS patients ${ }^{196}$.

\section{Neuroinflammation}

Ammonia extensively affects the function of astrocytes and microglia (Figure 2). Through several mechanisms including (1) quinolinic acid (QUIN) production, (2) NADPH oxidase (NOX) activity-induced reactive oxygen species (ROS) generation, (3) Toll-like receptor 4 (TLR-4) activation, and (4) extracellular-signal-regulated kinase (ERK) pathway stimulation, ammonia induces a transition from a resting state into reactive astroglia and microglia phenotype

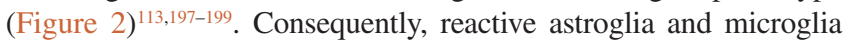
increase oxidative stress and stimulate the release of a range of proinflammatory cytokines including NF- $\kappa \mathrm{B}$, IL-1 $\beta$, and PGE2, leading to neuroinflammation and degeneration (Figure 2) ${ }^{200}$.

Emerging data indicate a role of QUIN in $\mathrm{ALS}^{201}$. Chen et al. detected overproduction of serum tryptophan, kynurenine and QUIN in the CSF of ALS patients compared to controls, concomitant with microglial activation and neuroinflammation (Figure 2) ${ }^{139}$. Similarly, experiments showed increased microglial and neutrophilderived NOX activity correlated with fast ALS progression ${ }^{202}$. In keeping with increased ammonia-induced inflammation, investigators showed TLR-4 activation, and elevated levels of various pro-inflammatory cytokines in $\mathrm{ALS}^{203,204}$.

\section{Clinical heterogeneities in ALS: the role of calcium- binding proteins (CaBPs)}

The postulated ammonia neurotoxicity as the sole cause of ALS raises an awkward question. If ammonia damages both upper and lower motor neurons equally, then why does ALS often deviate from its classical pattern, manifesting as either the upper or lower motor neuron dominant subtype ${ }^{8}$ ? Moreover, why it is a relatively rare disorder? These questions clearly indicate that a protective factor exists that counteracts ammonia toxicity, and that anatomicregion specific loss of this factor causes the clinical heterogeneities in its presentation.

One such neuroprotective factor identified in ALS is the ER family of calcium binding proteins (CaBPs) (Figure 1 and Figure 2) ${ }^{205}$. By regulating voltage-gated calcium ion channels, $\mathrm{CaBPs}$ reduce calcium overload and cytotoxicity, thus protecting neurons from cell death ${ }^{205}$. The CaBPs involved in motor neuron protection include calreticulin, parvalbumin, and calbindin which are distributed in anatomic region specific manner within motor neurons ${ }^{206,207}$. Calreticulin expression mainly occurs in limb-innervating lower motor neuron regions such as the lumbar spinal cord area and fast-fatigable motoneuron, whereas calbindin and parvalbumin are expressed in both lower and upper motor neurons ${ }^{206,207}$.

Differential anatomic region-specific distribution of CaBPs in the CNS partly explains different patterns of motor neurodegeneration ${ }^{206,208}$.
In the SOD1 G93A ALS mouse model, during the presymptomatic stage, fast-fatigable motoneuron denervation mainly accompanies calreticulin loss ${ }^{208,209}$. By contrast, investigators showed that loss of calbindin and parvalbumin correlated with both upper and lower motor neuron damage ${ }^{206}$.

\section{Region specific regulation of CaBPs: ER stress and bioenergetics}

How do neurons lose different $\mathrm{CaBPs}$ in different anatomic regions of the CNS? Research showed that ER stress downregulates calreticulin in limb-innervating lower motor neurons motor. In fact, calreticulin co-localises with the $\mathrm{ER}^{207}$. This accords with the finding that neuronal MMP-9-which enhances ER stress-selective damages fast fatigable lower motor neurons ${ }^{185}$. Additionally, since androgens modulate ER stress, this explains why sexual dimorphism occurs in lower motor neuron damage ${ }^{210}$. Interestingly, research revealed increased ER stress and reduced calreticulin in Alzheimer's disease $(\mathrm{AD})^{209}$. This explains why AD occasionally co-exists with motor neuron disease $\mathrm{e}^{211}$.

As for the causes of reduced parvalbumin and calbindin expression in ALS, research implicates impaired oxidative metabolism secondary to defective mitochondrial electron transport (the respiratory chain) system ${ }^{212,213}$. Indeed, of the five protein complexes of the mitochondrial respiratory chain, research has frequently showed reduced respiratory chain complex I and IV activity in sporadic ALS patients ${ }^{205,212}$. Within these two complexes, complex IV appears to be particularly involved in ALS. This chimes well with the fact that $90 \%$ of all parvalbumin and calbindin-immunoreactive cells showed dense staining for respiratory complex IV (cytochrome c oxidase) ${ }^{214}$. Furthermore, hyperhomocysteinaemia, found to be highly prevalent in ALS, damages mitochondria and suppresses respiratory complex IV activity ${ }^{37,215}$. Revealingly, compared to skeletal muscle, the EOMs have slow metabolism characterised by low complexes I and IV activities $(\sim 50 \%)$ yet elevated mitochondria density with increased complex I and IV levels (30\% to 2 times)_explaining why parvalbumin and calbindin levels remain relatively unaffected in $\mathrm{EOMs}^{205,216,217}$.

\section{The role of respiratory chain complex subunits}

Interestingly, alterations in mitochondrial respiratory chain complex subunits also partly determine the spectrum of motor neuron damage. Investigators reported that altered Cytochrome c oxidase subunit $\mathrm{Vb}$ caused spinobulbar muscular atrophy, whereas Cytochrome c oxidase subunit I microdeletion induced upper motor dominant motor neuron damage $\mathrm{e}^{218,219}$. Furthermore, deficiency of complex I involved lower motor neuron damage involving spinal and bulbar areas ${ }^{220}$. This fits with the findings that anatomic regionspecific differences in mitochondrial respiration contribute to the localized neurodegeneration ${ }^{221}$.

In summary, these findings suggest that the regional loss of CaBPs expression, dependent on ER stress and defective mitochondrial respiration in the brain determines the anatomically variable manifestation of ALS. Collectively, it is also clear that motor neuron degeneration depends not only on postulated ammonia neurotoxicity but also on deficits of CaBPs within motor neuron. 


\section{Biomarkers and therapeutics}

From this insight about ALS pathogenesis, diagnostic, disease monitoring and therapeutic measures emerge-fostering real hopes that ALS can be halted or even cured. Because ammonia is a volatile organic compound, excreted from breath and skin, an ammonia breath test would present a simple, reliable, robust, inexpensive and non-invasive tool for diagnosis and monitoring of ALS ${ }^{222}$. This ammonia breath test would prove invaluable in expediting drug discovery process. Aside from ammonia, gangliosides (e.g. Sialosylglobotetraosylceramide) and serum lysosomal enzymes could also serve as reliable adjuvant biomarkers of $\mathrm{ALS}^{142}$.

As for therapeutics, since ammonia toxicity appears to be a major player in ALS, ammonia-removal strategies seem to be the most effective strategy for ALS treatment ${ }^{223}$. Many existing ammonialowering agents including those that act on the hepatic urea cycle can be employed ${ }^{224,225}$. These could include salbutamol, conclevan, neomycin, sodium benzoate, ornithinephenyl acetate and L-ornithine aspartate $^{223,226,227}$. Moreover, since impaired fast-twitch skeletal muscle glycolysis plays a role in ALS, improving muscle glycolysis through various existing drugs such as serotonin agonists and AMPK agonists (e.g. D-xylose) is another promising pharmacological strategy ${ }^{228,229}$. Additional therapeutic strategies could involve correcting system metabolic defects such as hyperglucagonemia and acidosis ${ }^{60,68}$. Moreover, other potent therapeutic targets could involve MAPK inhibitors, $\mathrm{K}-\mathrm{Cl}$ co-transporters, and hexosaminidase agonists (e.g. Pyrimethamine) ${ }^{192,230,231}$. Finally, interventions that restore the levels of CaBPs should also be simultaneously applied for effective treatment.

\section{Summary}

ALS is a ghastly and incurable disease. Despite increasing wealth of data, ALS remains poorly understood. By analysing existing literature, this paper has not only identified important knowledge gaps in ALS aetiopathology but also filled them and tied them together. In doing so, this paper postulates a new integrative explanation of ALS and suggests potent therapeutic measures to treat ALS. Central to this explanation is the notion that ALS is a neurological disease of metabolic origin-resembling hepatocerebral degeneration ${ }^{223}$. This explanation posits that ALS pathology involves the interplay of two critical factors: 1) chronic hyperammonia caused by imbalanced interogan ammonia metabolism, mainly due to muscle and liver pathology (Figure 1 and Figure 2) altered CaBPs homeostasis, mainly due to increased ER stress and impaired mitochondrial respiration (Figure 1).

Considering all these together in sequence, impaired fast twitch skeletal muscle carbohydrate metabolism activates purinergic and amino acid catabolism, leading to a release of ammonia, a neurotoxin. Alternatively, ammonia toxicity can also be induced or exacerbated by other endogenous (e.g. cerebral deamination, intestinal ammoniagenesis) and exogenous sources (i.e. neurotoxins). Owing to concurrent liver pathology (e.g. hepatic steatosis) in ALS, impaired hepatic ammonia detoxification occurs. Consequently, ammonia levels progressively builds up, leading to chronic hyperammonia. Since ALS pathology also involves loss of neuroprotective CaBPs (i.e. calbindin, calreticulin and parvalbumin), ammonia neurotoxicity in the absence of CaBPs leads to ALS. Ammonia damages motor neurons through a range of pathways. These pathways include impaired macroautophagy-endolysosomal impairment, Golgi fragmentation, oxidative/nitrosative stress and reactive microglial and astrogliosis. These mechanisms explain a range of histopathological and neurophysiological hallmarks of ALS such as bunia bodies and neuronal hyperexcitability. Finally, since ALS appears to be associated with HD, dementia and Parkinsonism this framework can be generalised to explain these disorders ${ }^{33,89,90}$.

\section{Competing interests}

No competing interests were disclosed.

\section{Grant information}

The author(s) declared that no grants were involved in supporting this work.

\section{Acknowledgements}

I am very grateful to Prof. Rod Nicolson, at the University of Sheffield, for his kindness, constant support, and editorial guidance during this work. I am thankful to Prof. Paul Overton, at the University of Sheffield, for his incisive comments and criticisms. I am also thankful to Navin Shah and Nirav Parekh for their support.
1. Maessen M, Veldink JH, Onwuteaka-Philipsen BD, et al.: Euthanasia and physician-assisted suicide in amyotrophic lateral sclerosis: a prospective study. J Neurol. 2014; 261(10): 1894-901. PubMed Abstract | Publisher Full Text

2. Carus R: Motor neurone disease: a demeaning illness. Br Med J. 1980; 280(6212): 455-456.

PubMed Abstract | Publisher Full Text | Free Full Text

3. Henriques A, Gonzalez De Aguilar JL: Can transcriptomics cut the gordian knot of amyotrophic lateral sclerosis? Curr Genomics. 2011; 12(7): 506-515. PubMed Abstract | Publisher Full Text | Free Full Text

4. Stone N: Amyotrophic lateral sclerosis: a challenge for constant adaptation. J Neurosci Nurs. 1987; 19(3): 166-73.

PubMed Abstract
5. Bastos AF, Orsini M, Machado D, et al.: Amyotrophic lateral sclerosis: one or multiple causes? Neurol Int. 2011; 3(1): e4.

PubMed Abstract | Publisher Full Text | Free Full Text

6. Turner MR, Swash M, Ebers GC: Lockhart Clarke's contribution to the description of amyotrophic lateral sclerosis. Brain. 2010; 133(11): 3470-3479.

PubMed Abstract | Publisher Full Text | Free Full Text

7. Pansarasa O, Rossi D, Berardinelli A, et al:: Amyotrophic lateral sclerosis and skeletal muscle: an update. Mol Neurobiol. 2014; 49(2): 984-90. PubMed Abstract | Publisher Full Text

8. Swinnen B, Robberecht W: The phenotypic variability of amyotrophic lateral sclerosis. Nat Rev Neurol. 2014; 10(11): 661-670. PubMed Abstract | Publisher Full Tex 
9. Ferraiuolo L, Kirby J, Grierson AJ, et al: Molecular pathways of motor neuron injury in amyotrophic lateral sclerosis. Nat Rev Neurol. 2011; 7(11): 616-30. PubMed Abstract | Publisher Full Text

10. Chen S, Sayana $P$, Zhang X, et al.: Genetics of amyotrophic lateral sclerosis: an update. Mol Neurodegener. 2013; 8(1): 28

PubMed Abstract | Publisher Full Text | Free Full Text

11. Ferraiuolo L, De Bono JP, Heath PR, et al:: Transcriptional response of the neuromuscular system to exercise training and potential implications for ALS. J Neurochem. 2009; 109(6): 1714-24.

JubMed Abstract | Publisher Full Text

12. von Giesen HJ, Kaiser R, Köller H, et al.: Reversible ALS-like disorder in HIV infection. An ALS-like syndrome with new HIV infection and complete response to antiretroviral therapy. Neurology. 2002; 59(3): 474; author reply 474-5. PubMed Abstract

13. Turner MR, Bowser R, Bruijn L, et al.: Mechanisms, models and biomarkers in amyotrophic lateral sclerosis. Amyotroph Lateral Scler Frontotemporal Degener. 2013; 14(Suppl 1): 19-32.

PubMed Abstract | Publisher Full Text | Free Full Text

14. Dadon-Nachum M, Melamed E, Offen D: The "dying-back" phenomenon of motor neurons in ALS. $J$ Mol Neurosci. 2011; 43(3): 470-7.

PubMed Abstract | Publisher Full Tex

15. Sargsyan SA, Monk PN, Shaw PJ: Microglia as potential contributors to motor neuron injury in amyotrophic lateral sclerosis. Glia. 2005; 51(4): 241-53. PubMed Abstract | Publisher Full Text

16. Shaw PJ, Ince PG: Glutamate, excitotoxicity and amyotrophic lateral sclerosis. J Neurol. 1997; 244(Suppl 2): S3-14.

PubMed Abstract | Publisher Full Text

17. Ince PG, Lowe J, Shaw PJ: Amyotrophic lateral sclerosis: current issues in classification, pathogenesis and molecular pathology. Neuropathol App Neurobiol. 1998; 24(2): 104-17.

PubMed Abstract | Publisher Full Text

18. Bruijn LI, Miller TM, Cleveland DW: Unraveling the mechanisms involved in motor neuron degeneration in ALS. Annu Rev Neurosci. 2004; 27: 723-49. PubMed Abstract | Publisher Full Text

19. Dupuis L, Pradat PF, Ludolph AC, et al:: Energy metabolism in amyotrophic lateral sclerosis. Lancet Neurol. 2011; 10(1): 75-82.

PubMed Abstract | Publisher Full Text

20. Ilieva $\mathrm{H}$, Polymenidou M, Cleveland DW: Non-cell autonomous toxicity in neurodegenerative disorders: ALS and beyond. J Cell Biol. 2009; 187(6): 761-72. PubMed Abstract | Publisher Full Text | Free Full Text

21. Finkelstein A, Kunis G, Seksenyan A, et al:: Abnormal changes in NKT cells, the IGF-1 axis, and liver pathology in an animal model of ALS. PLOS One. 2011; 6(8): e22374.

PubMed Abstract | Publisher Full Text | Free Full Text

22. Nodera $\mathrm{H}$, Takamatsu N, Muguruma N, et al: Frequent hepatic steatosis in amyotrophic lateral sclerosis: Implication for systemic involvement. Neurol Clin Neurosci. 2015; 3(2): 58-62.

Publisher Full Text

23. Bennett EJ, Mead RJ, Azzouz M, et al: Early detection of motor dysfunction in the SOD1G93A mouse model of Amyotrophic Lateral Sclerosis (ALS) using home cage running wheels. PLoS One. 2014; 9(9): e107918.

PubMed Abstract | Publisher Full Text | Free Full Text

24. Frey D, Schneider C, Xu L, et al:: Early and selective loss of neuromuscula synapse subtypes with low sprouting competence in motoneuron diseases. J Neurosci. 2000; 20(7): 2534-42.

PubMed Abstract

25. Dobrowolny $\mathrm{G}$, Aucello $\mathrm{M}$, Rizzuto $\mathrm{E}$, et al.: Skeletal muscle is a primary target of SOD1G93A-mediated toxicity. Cell Metab. 2008; 8(5): 425-36.

PubMed Abstract | Publisher Full Tex

26. Tsao TS, Li J, Chang KS, et al:: Metabolic adaptations in skeletal muscle overexpressing GLUT4: effects on muscle and physical activity. FASEB J. 2001; 15(6): 958-69.

PubMed Abstract | Publisher Full Text

27. Derave W, Van Den Bosch L, Lemmens G, et al.: Skeletal muscle properties in a transgenic mouse model for amyotrophic lateral sclerosis: effects of creatine treatment. Neurobiol Dis. 2003; 13(3): 264-72.

PubMed Abstract | Publisher Full Text

28. Toivonen JM, Manzano R, Oliván S, et al:: MicroRNA-206: a potential circulating biomarker candidate for amyotrophic lateral sclerosis. PLOS One. 2014; 9(2): e89065

PubMed Abstract | Publisher Full Text | Free Full Text

29. Fogarty MJ, Noakes PG, Bellingham MC: Motor cortex layer V pyramidal neurons exhibit dendritic regression, spine loss, and increased synaptic excitation in the presymptomatic hSOD1(G93A) mouse model of amyotrophic lateral sclerosis. J Neurosci. 2015; 35(2): 643-7.

PubMed Abstract | Publisher Full Tex

30. Graham JM, Papadakis N, Evans J, et al:: Diffusion tensor imaging for the assessment of upper motor neuron integrity in ALS. Neurology. 2004; 63(11) 2111-9.

PubMed Abstract | Publisher Full Text

31. Ravits JM, La Spada AR: ALS motor phenotype heterogeneity, focality, and spread: Deconstructing motor neuron degeneration. Neurology. 2009; 73(10): 805-811.

PubMed Abstract | Publisher Full Text | Free Full Text
32. Nakano $\mathrm{Y}$, Hirayama $\mathrm{K}$, Terao $\mathrm{K}$ : Hepatic ultrastructural changes and liver dysfunction in amyotrophic lateral sclerosis. Arch Neurol. 1987; 44(1): 103-6. PubMed Abstract | Publisher Full Text

33. Fisman M: Hepatic ultrastructural change and liver dysfunction in amyotrophic lateral sclerosis. Arch Neurol. 1987; 44(10): 997.

PubMed Abstract | Publisher Full Text

34. Zolkipli Z, Sherlock M, Biggar WD, et al.: Abnormal fatty acid metabolism in spinal muscular atrophy may predispose to perioperative risks. Eur J Paediatr Neurol. 2012; 16(5): 549-53. PubMed Abstract | Publisher Full Tex

35. Shababi M, Lorson CL, Rudnik-Schoneborn SS: Spinal muscular atrophy: a motor neuron disorder or a multi-organ disease? J Anat. 2014; 224(1): 15-28. PubMed Abstract | Publisher Full Text

36. Fusco A, Miele L, D'Uonnolo A, et al:: Nonalcoholic fatty liver disease is associated with increased GHBP and reduced GH/IGF-I levels. Clin Endocrinol (Oxf). 2012; 77(4): 531-6.

PubMed Abstract | Publisher Full Text

37. Zoccolella S, Bendotti C, Beghi E, et al.: Homocysteine levels and amyotrophic lateral sclerosis: A possible link. Amyotroph Lateral Scler. 2010; 11(1-2): 140-7. PubMed Abstract | Publisher Full Text

38. DiBello PM, Dayal S, Kaveti S, et al:: The nutrigenetics of hyperhomocysteinemia: quantitative proteomics reveals differences in the methionine cycle enzymes of gene-induced versus diet-induced hyperhomocysteinemia. Mol Cell Proteomics. 2010; 9(3): 471-85. PubMed Abstract | Publisher Full Text | Free Full Text

39. Merriman RB: Nonalcoholic fatty liver disease and HIV infection. Curr HIV/AIDS Rep. 2006; 3(3): 113-7.

PubMed Abstract | Publisher Full Tex

40. Zein CO: Clearing the smoke in chronic liver diseases. Hepatology. 2010; 51(5): $1487-1490$.

PubMed Abstract | Publisher Full Text | Free Full Text

41. Agrawal P, Pandey A, Sompura S, et al:: A rare case report showing direct association between hepatitis B and bulbar palsy. J Assoc Physicians India. 2014; 62(3): 267-8. PubMed Abstract

42. Hino H, Kusuhara T, Kaji M, et al.: Significance of hepatitis B virus antibody in motor neuron disease. Rinsho Shinkeigaku. 1995; 35(4): 341-3. PubMed Abstract

43. Li H, Zhu W, Zhang L, et al.: The metabolic responses to hepatitis B virus infection shed new light on pathogenesis and targets for treatment. Sci Rep. 2015; 5: 8421.

PubMed Abstract | Publisher Full Text | Free Full Text

44. Gupta G, Qin H, Song J: Intrinsically unstructured domain 3 of hepatitis $C$ Virus NS5A forms a "fuzzy complex" with VAPB-MSP domain which carries ALS-causing mutations. PLoS One. 2012; 7(6): e39261.

PubMed Abstract | Publisher Full Text | Free Full Text

45. Fargion S, Mattioli M, Fracanzani AL, et al.: Hyperferritinemia, iron overload, and multiple metabolic alterations identify patients at risk for nonalcoholic steatohepatitis. Am J Gastroenterol. 2001; 96(8): 2448-55.

PubMed Abstract | Publisher Full Text

46. Veyrat-Durebex $\mathrm{C}$, Corcia $\mathrm{P}$, Mucha A, et al.: Iron metabolism disturbance in a French cohort of ALS patients. BioMed Research International. 2014; 2014 485723.

PubMed Abstract | Publisher Full Text | Free Full Text

47. Slowik A, Tomik B, Wolkow PP, et al:: Paraoxonase gene polymorphisms and sporadic ALS. Neurology. 2006; 67(5): 766-70.

PubMed Abstract | Publisher Full Tex

48. Garcia-Heredia A, Kensicki E, Mohney RP, et al.: Paraoxonase-1 deficiency is associated with severe liver steatosis in mice fed a high-fat high-cholesterol diet: a metabolomic approach. J Proteome Res. 2013; 12(4): 1946-55. PubMed Abstract | Publisher Full Text

49. Li T, Owsley E, Matozel M, et al:: Transgenic expression of cholesterol 7alpha-hydroxylase in the liver prevents high-fat diet-induced obesity and insulin resistance in mice. Hepatology. 2010; 52(2): 678-90. PubMled Abstract | Publisher Full Text | Free Full Text

50. Dai $\mathrm{D}$, Mills $\mathrm{PB}$, Footitt $\mathrm{E}$, et al:: Liver disease in infancy caused by oxysterol $7 \alpha$-hydroxylase deficiency: successful treatment with chenodeoxycholic acid. $J$ Inherit Metab Dis. 2014; 37(5): 851-61. PubMed Abstract | Publisher Full Text

51. Tsaousidou MK, Ouahchi K, Warner TT, et al.: Sequence alterations within CYP7B1 implicate defective cholesterol homeostasis in motor-neuron degeneration. Am J Hum Genet. 2008; 82(2): 510-5. PubMed Abstract | Publisher Full Text | Free Full Text

52. Fittschen M, Lastres-Becker I, Halbach MV, et al:: Genetic ablation of ataxin-2 increases several global translation factors in their transcript abundance but decreases translation rate. Neurogenetics. 2015. PubMed Abstract | Publisher Full Text

53. Li P, Ruan X, Yang L, et al.: A liver-enriched long non-coding RNA, IncLSTR, regulates systemic lipid metabolism in mice. Cell Metab. 2015; 21(3): 455-67. PubMed Abstract | Publisher Full Text | Free Full Text

54. van den Heuvel DM, Harschnitz $\mathrm{O}$, van den Berg LH, et al:: Taking a risk: a therapeutic focus on ataxin-2 in amyotrophic lateral sclerosis? Trends Mol Med. 2014; 20(1): 25-35.

PubMed Abstract [ Publisher Full Text 
55. Onodera O, Akihiro S, Takuya $\mathrm{K}$, et al.: What is the key player in TDP-43 pathology in ALS: Disappearance from the nucleus or inclusion formation in the cytoplasm? Neurology and Clinical Neuroscience. 2013; 1(1): 11-17. Publisher Full Text

56. Su Q, Baker C, Christian P, et al:: Hepatic mitochondrial and ER stress induced by defective PPAR $\alpha$ signaling in the pathogenesis of hepatic steatosis. Am J Physiol Endocrinol Metab. 2014; 306(11): E1264-73.

PubMed Abstract | Publisher Full Text | Free Full Text

57. Pereira C: Crosstalk between Endoplasmic Reticulum Stress and Protein Misfolding in Neurodegenerative Diseases. ISRN Cell Biology. 2013; 2013: 22. Publisher Full Text

58. Vollrath JT, Sechi A, Dreser A, et al.: Loss of function of the ALS protein SigR1 leads to ER pathology associated with defective autophagy and lipid raft disturbances. Cell Death Dis. 2014; 5: e1290.

PubMed Abstract | Publisher Full Text

59. Moriwaka F, Tashiro K, Shima K, et al:: Glucagon and ALS. Neurology. 1993; 43(5): 1061. PubMed Abstract

60. Dodge JC, Treleaven CM, Fidler JA, et al:: Metabolic signatures of amyotrophic lateral sclerosis reveal insights into disease pathogenesis. Proc Natl Acad Sci U S A. 2013; 110(26): 10812-7.

PubMed Abstract | Publisher Full Text | Free Full Text

61. Goto F, Kitamura A, Koto A, et al:: Abnormal insulin secretion in amyotrophic lateral sclerosis. J Neurol Sci. 1972; 16(2): 201-7.

PubMed Abstract | Publisher Full Text

62. Pradat PF, Bruneteau G, Gordon PH, et al:: Impaired glucose tolerance in patients with amyotrophic lateral sclerosis. Amyotroph Lateral Scler. 2010; 11(1-2): 166-71.

PubMed Abstract | Publisher Full Text

63. Nassir F, Ibdah JA: Role of mitochondria in nonalcoholic fatty liver disease. Int J Mol Sci. 2014; 15(5): 8713-8742.

PubMed Abstract | Publisher Full Text | Free Full Text

64. Ikeda K, Hirayama T, Takazawa T, et al:: Relationships between disease progression and serum levels of lipid, urate, creatinine and ferritin in Japanese patients with amyotrophic lateral sclerosis: a cross-sectional study. Intern Med. 2012; 51(12): 1501-8.

PubMed Abstract | Publisher Full Text

65. den Boer M, Voshol PJ, Kuipers F, et al:: Hepatic steatosis: A mediator of the metabolic syndrome. Lessons from animal models. Arterioscler Thromb Vasc Biol. 2004; 24(4): 644-649.

PubMed Abstract | Publisher Full Text

66. Akasaki $\mathrm{Y}$, Ouchi N, Izumiya $\mathrm{Y}$, et al.: Glycolytic fast-twitch muscle fiber restoration counters adverse age-related changes in body composition and metabolism. Aging Cell. 2014; 13(1): 80-91.

PubMed Abstract | Publisher Full Text | Free Full Text

67. Li Y, Chigurupati S, Holloway HW, et al:: Exendin-4 ameliorates motor neuron degeneration in cellular and animal models of amyotrophic lateral sclerosis. PLoS One. 2012; 7(2): e32008.

PubMed Abstract | Publisher Full Text | Free Full Text

68. Tanaka $\mathrm{K}$, Masaki $\mathrm{Y}$, Tanaka $\mathrm{M}$, et al: Exenatide improves hepatic steatosis by enhancing lipid use in adipose tissue in nondiabetic rats. World $J$ Gastroenterol. 2014; 20(10): 2653-63.

PubMed Abstract | Publisher Full Text | Free Full Text

69. Dupuis L, Loeffler JP: Neuromuscular junction destruction during amyotrophic lateral sclerosis: insights from transgenic models. Curr Opin Pharmacol. 2009; 9(3): 341-6.

PubMed Abstract | Publisher Full Text

70. Dupuis L, Oudart $H$, René $F$, et al:: Evidence for defective energy homeostasis in amyotrophic lateral sclerosis: benefit of a high-energy diet in a transgenic mouse model. Proc Natl Acad Sci U S A. 2004; 101(30): 11159-64. PubMed Abstract | Publisher Full Text | Free Full Text

71. Dupuis L, di Scala F, Rene F, et al:: Up-regulation of mitochondrial uncoupling protein 3 reveals an early muscular metabolic defect in amyotrophic lateral sclerosis. FASEB J. 2003; 17(14): 2091-3. PubMed Abstract | Publisher Full Text

72. Bernardini C, Censi F, Lattanzi W, et al:: Mitochondrial network genes in the skeletal muscle of amyotrophic lateral sclerosis patients. PLoS One. 2013; 8(2): e57739.

PubMed Abstract | Publisher Full Text | Free Full Text

73. Brockington $\mathrm{A}$, Heath $\mathrm{PR}$, Holden $\mathrm{H}$, et al.: Downregulation of genes with a function in axon outgrowth and synapse formation in motor neurones of the VEGFdelta/delta mouse model of amyotrophic lateral sclerosis. BMC Genomics. 2010; 11: 203.

PubMed Abstract | Publisher Full Text | Free Full Text

74. Mali Y, Zisapels N: Gain of interaction of ALS-linked G93A superoxide dismutase with cytosolic malate dehydrogenase. Neurobiol Dis. 2008; 32(1): 133-41.

PubMed Abstract | Publisher Full Text

75. Dunckley T, Huentelman MJ, Craig DW, et al:: Whole-genome analysis of sporadic amyotrophic lateral sclerosis. N Engl J Med. 2007; 357(8): 775-88. PubMed Abstract | Publisher Full Text

76. Rose AJ, Richter EA: Skeletal muscle glucose uptake during exercise: how is it regulated? Physiology (Bethesda). 2005; 20: 260-270.

PubMed Abstract | Publisher Full Tex
77. Smittkamp SE, Morris JK, Bomhoff GL, et al.: SOD1-G93A mice exhibit muscle-fiber-type-specific decreases in glucose uptake in the absence of whole-body changes in metabolism. Neurodegener Dis. 2014; 13(1): 29-37. PubMed Abstract | Publisher Full Text | Free Full Text

78. Perera ND, Sheean RK, Scott JW, et al.: Mutant TDP-43 deregulates AMPK activation by PP2A in ALS models. PLoS One. 2014; 9(3): e90449. PubMed Abstract | Publisher Full Text | Free Full Text

79. Gumà A, Martínez-Redondo V, López-Soldado I, et al:: Emerging role of neuregulin as a modulator of muscle metabolism. Am J Physiol Endocrino Metab. 2010; 298(4): E742-E750.

PubMed Abstract | Publisher Full Tex

80. Coughlan KS, Mitchem MR, Hogg MC, et al: "Preconditioning" with latrepirdine, an adenosine 5'-monophosphate-activated protein kinase activator, delays amyotrophic lateral sclerosis progression in SOD1(G93A) mice. Neurobiol Aging. 2015; 36(2): 1140-50.

PubMed Abstract | Publisher Full Text

81. Takahashi $Y$, Fukuda $Y$, Yoshimura J, et al:: ERBB4 mutations that disrupt the neuregulin-ErbB4 pathway cause amyotrophic lateral sclerosis type 19. Am J Hum Genet. 2013; 93(5): 900-5.

PubMed Abstract | Publisher Full Text | Free Full Text

82. Shaw PJ: Motor neurone disease. BMJ. 1999; 318(7191): 1118-1121. PubMed Abstract | Publisher Full Text | Free Full Text

83. Porter JD, Khanna S, Kaminski HJ, et al.: Extraocular muscle is defined by a fundamentally distinct gene expression profile. Proc Natl Acad Sci U S A. 2001; 98(21): 12062-12067. PubMed Abstract | Publisher Full Text | Free Full Text

84. Broberg S, Sahlin K: Adenine nucleotide degradation in human skeletal muscle during prolonged exercise. J Appl Physiol (1985). 1989; 67(1): 116-22. PubMed Abstract

85. Meyer RA, Terjung RL: Differences in ammonia and adenylate metabolism in contracting fast and slow muscle. Am J Physiol. 1979; 237(3): C111-8. PubMed Abstract

86. Phillips SC: The toxicity to rat cerebral cortex or topical applications of acetaldehyde, ammonia or bilirubin. Neuropathol Appl Neurobiol. 1981; 7(3): 205-16. PubMed Abstract | Publisher Full Text

87. Clay AS, Hainline BE: Hyperammonemia in the ICU. Chest. 2007; 132(4): 1368-1378. PubMed Abstract | Publisher Full Text

88. Walker V: Severe hyperammonaemia in adults not explained by liver disease. Ann Clin Biochem. 2012; 49(Pt 3): 214-28.

PubMed Abstract | Publisher Full Text

89. Seiler N: Ammonia and Alzheimer's disease. Neurochem Int. 2002; 41(2-3): 189-207.

PubMed Abstract | Publisher Full Text

90. Chiang MC, Chen HM, Lee YH, et al:: Dysregulation of C/EBPalpha by mutant Huntingtin causes the urea cycle deficiency in Huntington's disease. Hum Mol Genet. 2007; 16(5): 483-98

PubMed Abstract | Publisher Full Text

91. Thomsen KL, Grønbæk H, Glavind E, et al:: Experimental nonalcoholic steatohepatitis compromises ureagenesis, an essential hepatic metabolic function. Am J Physiol Gastrointest Liver Physiol. 2014; 307(3): G295-301. PubMed Abstract | Publisher Full Text

92. Eichler M: Psychological changes associated with induced hyperammonemia Science. 1964; 144(3620): 886-8.

PubMed Abstract | Publisher Full Text

93. Nardone $\mathrm{R}$, Buratti $\mathrm{T}$, Oliviero A, et al: Corticospinal involvement in patients with a portosystemic shunt due to liver cirrhosis: a MEP study. $J$ Neurol. 2006; 253(1): 81-5.

PubMed Abstract | Publisher Full Text

94. Nardone R, Höller Y, Storti M, et al:: Spinal cord involvement in patients with cirrhosis. World J Gastroenterol. 2014; 20(10): 2578-85. PubMed Abstract | Publisher Full Text | Free Full Text

95. Giangaspero F, Dondi C, Scarani P, et al:: Degeneration of the corticospinal tract following portosystemic shunt associated with spinal cord infarction. Virchows Arch A Pathol Anat Histopathol. 1985; 406(4): 475-81. PubMed Abstract | Publisher Full Text

96. Lee KS, Kelly DL Jr: Amyotrophic lateral sclerosis and severe cervical spondylotic myelopathy in a patient with a posterior fossa arachnoid cyst: diagnostic dilemma. South Med J. 1987; 80(12): 1580-3. PubMed Abstract

97. Braissant $\mathrm{O}$, McLin VA, Cudalbu C: Ammonia toxicity to the brain. $J$ Inherit Metab Dis. 2013; 36(4): 595-612. PubMed Abstract | Publisher Full Text

98. Patten BM, Kurlander HM, Evans B: Free amino acid concentrations in spinal tissue from patients dying of motor neuron disease. Acta Neurol Scand. 1982 66(5): 594-9.

PubMed Abstract | Publisher Full Text

99. Vanacore N, Binazzi A, Bottazzi M, et al.: Amyotrophic lateral sclerosis in an Italian professional soccer player. Parkinsonism Relat Disord. 2006; 12(5): 327-9. PubMed Abstract | Publisher Full Text

100. Corbett AJ, Griggs RC, Moxley RT 3rd: Skeletal muscle catabolism in amyotrophic lateral sclerosis and chronic spinal muscular atrophy. Neurology. 1982; 32(5): 550-2.

PubMed Abstract 
101. Kabadi UM, Eisenstein $A B$, Konda J: Elevated plasma ammonia level in hepatic cirrhosis: role of glucagon. Gastroenterology. 1985; 88(3): 750-6. PubMed Abstract

102. Hubbard RW, Will AD, Peterson GW, et al:: Elevated plasma glucagon in amyotrophic lateral sclerosis. Neurology. 1992; 42(8): 1532-4. PubMed Abstract | Publisher Full Text

103. Brouns F, Beckers E, Wagenmakers AJ, et al:: Ammonia accumulation during highly intensive long-lasting cycling: individual observations. Int J Sports Med. 1990; 11(Suppl 2): S78-84. PubMed Abstract | Publisher Full Text

104. Tomomura M, Imamura $\mathrm{Y}$, Horiuchi M, et al:: Abnormal expression of urea cycle enzyme genes in juvenile visceral steatosis (jvs) mice. Biochim Biophys Acta. 1992; 1138(2): 167-171. PubMed Abstract | Publisher Full Text

105. Ilzecka J, Stelmasiak Z, Solski J, et al.: Plasma amino acids concentration in amyotrophic lateral sclerosis patients. Amino Acids. 2003; 25(1): 69-73. PubMed Abstract | Publisher Full Text

106. Nissim I, Cattano C, Lin Z, et al:: Acid-base regulation of hepatic glutamine metabolism and ureagenesis: study with 15N. J Am Soc Nephrol. 1993; 3(7): 1416-27.

PubMed Abstract

107. Bos IWM, Hoogland G, Meine Jansen CF, et al.: Increased glutamine synthetase but normal EAAT2 expression in platelets of ALS patients. Neurochem Int 2006; 48(4): 306-311.

PubMed Abstract | Publisher Full Tex

108. Duarte-Rojo A, Torres-Vega MA, Villamil-Ramírez H, et al:: Changes in periphera blood mononuclear cells glutamine synthetase mRNA after exercise in healthy volunteers: exploring an alternative proposal for non hepatic ammonia metabolism. Rev Invest Clin. 2012; 64(2): 164-72. PubMed Abstract

109. Bame M, Grier RE, Needleman R, et al:: Amino acids as biomarkers in the SOD1(G93A) mouse model of ALS. Biochim Biophys Acta. 2014; 1842(1): 79-87. PubMed Abstract | Publisher Full Text

110. Gonzalez de Aguilar JL, Niederhauser-Wiederkehr C, Halter B, et al: Gene profiling of skeletal muscle in an amyotrophic lateral sclerosis mouse model. Physiol Genomics. 2008; 32(2): 207-18 PubMed Abstract | Publisher Full Tex

111. Gonzalez de Aguilar JL, Gordon JW, René F, et al: A mouse model of familia amyotrophic lateral sclerosis expressing a mutant superoxide dismutase 1 shows evidence of disordered transport in the vasopressin hypothalamoneurohypophysial axis. Eur J Neurosci. 1999; 11(12): 4179-87. PubMed Abstract | Publisher Full Text

112. Hiroyama M, Aoyagi T, Fujiwara $\mathrm{Y}$, et al:: Hyperammonaemia in V1a vasopressin receptor knockout mice caused by the promoted proteolysis and reduced intrahepatic blood volume. J Physiol. 2007; 581(Pt 3): 1183-92. PubMed Abstract | Publisher Full Text | Free Full Text

113. Bobermin LD, Quincozes-Santos A, Guerra MC et al: Resveratrol prevents ammonia toxicity in astroglial cells. PLoS One. 2012; 7(12): e52164. PubMed Abstract | Publisher Full Text | Free Full Text

114. Smith W, Diaz GA, Lichter-Konecki U, et al.: Ammonia control in children ages 2 months through 5 years with urea cycle disorders: comparison of sodium phenylbutyrate and glycerol phenylbutyrate. J Pediatr. 2013; 162(6): 1228-34. PubMed Abstract | Publisher Full Text | Free Full Text

115. Lee J, Ryu H, Kowall NW: Motor neuronal protection by L-arginine prolongs survival of mutant SOD1 (G93A) ALS mice. Biochem Biophys Res Commun. 2009; 384(4): 524-9. PubMed Abstract | Publisher Full Text | Free Full Text

116. Mizutani N, Kato T, Maehara M, et al:: Oral administration of arginine and citrulline in the treatment of lysinuric protein intolerance. Tohoku J Exp Med. 1984; 142(1): 15-24. PubMed Abstract | Publisher Full Text

117. Kira $Y$, Nishikawa M, Ochi A, et al.: L-carnitine suppresses the onset of neuromuscular degeneration and increases the life span of mice with familial amyotrophic lateral sclerosis. Brain Res. 2006; 1070(1): 206-14. PubMed Abstract | Publisher Full Text

118. Mancuso R, del Valle J, Modol L, et al.: Resveratrol improves motoneuron function and extends survival in SOD1(G93A) ALS mice. Neurotherapeutics. 2014; 11(2): 419-32.

PubMed Abstract | Publisher Full Text | Free Full Text

119. Nunn PB, Ponnusamy M: Beta-N-methylaminoalanine (BMAA): metabolism and metabolic effects in model systems and in neural and other tissues of the rat in vitro. Toxicon. 2009; 54(2): 85-94.

PubMed Abstract | Publisher Full Text

120. de Munck E, Muñoz-Sáez E, Antonio MT, et al.: Effect of $\beta$-N-methylamino-Lalanine on oxidative stress of liver and kidney in rat. Environ Toxicol Pharmacol. 2013; 35(2): 193-9.

PubMed Abstract | Publisher Full Text

121. O'Neal RM, Chen CH, Reynolds CS, et al:: The 'neurotoxicity' of L-2,4diaminobutyric acid. Biochem J. 1968; 106(3): 699-706. PubMed Abstract | Free Full Text

122. Cheema PS, Malathi K, Padmanaban G, et al:: The neurotoxicity of beta-N-oxalylL-alphabeta-diaminopropionic acid, the neurotoxin from the pulse Lathyrus sativus. Biochem J. 1969; 112(1): 29-33.

PubMed Abstract | Free Full Text
123. Doi $\mathrm{H}$, Kikuchi $\mathrm{H}$, Murai $\mathrm{H}$, et al: Motor neuron disorder simulating ALS induced by chronic inhalation of pyrethroid insecticides. Neurology. 2006 67(10): 1894-5.

PubMed Abstract | Publisher Full Text

124. Kumar A, Sharma B, Pandey RS: Cypermethrin induced alterations in nitrogen metabolism in freshwater fishes. Chemosphere. 2011; 83(4): 492-501. PubMed Abstract | Publisher Full Text

125. Tada M, Coon EA, Osmand AP, et al: Coexistence of Huntington's disease and amyotrophic lateral sclerosis: a clinicopathologic study. Acta Neuropathol. 2012; 124(5): 749-60.

PubMed Abstract | Publisher Full Text | Free Full Text

126. Sadeghian $\mathrm{H}, \mathrm{O}$ 'Suilleabhain $\mathrm{PE}$, Battiste $\mathrm{J}$, et al.: Huntington chorea presenting with motor neuron disease. Arch Neurol 2011; 68(5): 650-2.

PubMed Abstract | Publisher Full Text

127. Chiang MC, Chern Y, Juo CG: The dysfunction of hepatic transcriptional factors in mice with Huntington's Disease. Biochim Biophys Acta. 2011; 1812(9): $1111-1120$.

PubMed Abstract | Publisher Full Text

128. Hensman Moss DJ, Poulter M, Beck J, et al.: C9orf72 expansions are the most common genetic cause of Huntington disease phenocopies. Neurology. 2014 82(4): 292-9.

PubMed Abstract | Publisher Full Text | Free Full Text

129. Berger R, Mezey E, Clancy KP, et al:: Analysis of aldehyde oxidase and xanthine dehydrogenase/oxidase as possible candidate genes for autosomal recessive familial amyotrophic lateral sclerosis. Somat Cell Mol Genet. 1995; 21(2): 121-31

PubMed Abstract | Publisher Full Text

130. Ekblom J, Aquilonius SM, Jossan SS: Differential increases in catecholamin metabolizing enzymes in amyotrophic lateral sclerosis. Exp Neurol. 1993; 123(2): 289-94.

PubMed Abstract | Publisher Full Text

131. Orru S, Mascia V, Casula M, et al:: Association of monoamine oxidase B allele with age at onset in amyotrophic lateral sclerosis. Neuromuscul Disord. 1999; 9(8): 593-7. PubMed Abstract | Publisher Full Text

132. Skowronska $\mathrm{M}$, Albrecht $\mathrm{J}$ : Oxidative and nitrosative stress in ammonia neurotoxicity. Neurochem Int. 2013; 62(5): 731-7. PubMed Abstract | Publisher Full Text

133. Butterworth RF: Glutamate transporters in hyperammonemia. Neurochem Int 2002; 41(2-3): 81-85. PubMed Abstract | Publisher Full Tex

134. Tsuboi M, Harasawa K, Izawa T, et al.: Intralysosomal pH and release of Iysosomal enzymes in the rat liver after exhaustive exercise. $J$ Appl Physio (1985). 1993; 74(4): 1628-34. PubMed Abstract

135. Cagnon L, Braissant O: Role of caspases, calpain and cdk5 in ammoniainduced cell death in developing brain cells. Neurobiol Dis. 2008. 32(2): 281-92. PubMed Abstract | Publisher Full Text

136. Gorg B, Karababa A, Shafigullina A, et al.: Ammonia-induced senescence in cultured rat astrocytes and in human cerebral cortex in hepatic encephalopathy. Glia. 2015; 63(1): 37-50. PubMed Abstract | Publisher Full Text

137. Yamanaka K, Chun SJ, Boillee S, et al:: Astrocytes as determinants of disease progression in inherited amyotrophic lateral sclerosis. Nat Neurosci. 2008; 11(3): 251-3.

PubMed Abstract | Publisher Full Text | Free Full Text

138. Nicaise $C$, Mitrecic $D$, Demetter $P$, et al.: Impaired blood-brain and blood-spina cord barriers in mutant SOD1-linked ALS rat. Brain Res. 2009; 1301: 152-62. PubMed Abstract | Publisher Full Text

139. Chen $\mathrm{Y}$, Stankovic R, Cullen KM, et al:: The kynurenine pathway and inflammation in amyotrophic lateral sclerosis. Neurotox Res. 2010; 18(2): $132-42$

PubMed Abstract | Publisher Full Text

140. Okamoto K, Hirai S, Amari M, et al:: Bunina bodies in amyotrophic latera sclerosis immunostained with rabbit anti-cystatin C serum. Neurosci Lett. 1993; 162(1-2): $125-8$ PubMed Abstract | Publisher Full Text

141. van Dis V, Kuijpers M, Haasdijk ED, et al:: Golgi fragmentation precedes neuromuscular denervation and is associated with endosome abnormalities in SOD1-ALS mouse motor neurons. Acta Neuropathol Commun. 2014; 2: 38 PubMed Abstract | Publisher Full Text | Free Full Text

142. Kundu SK, Harati $Y$, Misra LK: Sialosylglobotetraosylceramide: a marker for amyotropic lateral sclerosis. Biochem Biophys Res Commun. 1984; 118(1): 82-9. PubMed Abstract

143. Bajaj NP: Cyclin-dependent kinase-5 (CDK5) and amyotrophic lateral sclerosis. Amyotroph Lateral Scler Other Motor Neuron Disord. 2000; 1(5): 319-27. PubMed Abstract | Publisher Full Text

144. Okamoto K, Hirai S, Shoji M, et al:: Axonal swellings in the corticospinal tracts in amyotrophic lateral sclerosis. Acta Neuropathol. 1990; 80(2): 222-6. PubMed Abstract | Publisher Full Text

145. Kihira T, Mizusawa $\mathrm{H}$, Tada J, et al.: Lewy body-like inclusions in Onuf's nucleus from two cases of sporadic amyotrophic lateral sclerosis. J Neurol Sci. 1993; 115(1): 51-7.

PubMed Abstract | Publisher Full Text 
146. Sahenk Z, Brown A: Weak-base amines inhibit the anterograde-to-retrograde conversion of axonally transported vesicles in nerve terminals. $J$ Neurocytol. 1991; 20(5): 365-375

PubMed Abstract | Publisher Full Text

147. Dean RT, Jessup W, Roberts CR: Effects of exogenous amines on mammalian cells, with particular reference to membrane flow. Biochem J. 1984; 217(1): 27-40. PubMed Abstract | Free Full Text

148. Shacka JJ, Klocke BJ, Young C, et al.: Cathepsin D deficiency induces persistent neurodegeneration in the absence of Bax-dependent apoptosis. $J$ Neurosci. 2007; 27(8): 2081-90. PubMed Abstract | Publisher Full Text

149. Chen S, Zhang $X$, Song L, et al:: Autophagy dysregulation in amyotrophic lateral sclerosis. Brain Pathol. 2012; 22(1): 110-6. PubMed Abstract | Publisher Full Text

150. Rubinsztein DC, Ravikumar B, Acevedo-Arozena A, et al.: Dyneins, autophagy, aggregation and neurodegeneration. Autophagy. 2005; 1(3): 177-8. PubMed Abstract | Publisher Full Text

151. Hafezparast M, Klocke R, Ruhrberg C, et al:: Mutations in dynein link motor neuron degeneration to defects in retrograde transport. Science. 2003; 300(5620): 808-12.

PubMed Abstract | Publisher Full Text

152. Wilson ME, Boumaza I, Bowser R: Measurement of cystatin $C$ functional activity in the cerebrospinal fluid of amyotrophic lateral sclerosis and control subjects. Fluids Barriers CNS. 2013; 10(1): 15. PubMed Abstract | Publisher Full Text | Free Full Text

153. Yates $\mathrm{CM}$, Wilson $\mathrm{H}$, Davidson $\mathrm{D}$ : Lysosomal enzymes in motor neurone disease and multiple sclerosis. Clin Chim Acta. 1973; 47(3): 397-402. PubMed Abstract | Publisher Full Text

154. Nagy L, Kusstatscher S, Hauschka PV, et al:: Role of cysteine proteases and protease inhibitors in gastric mucosal damage induced by ethanol or ammonia in the rat. J Clin Invest. 1996; 98(4): 1047-1054. PubMed Abstract | Publisher Full Text | Free Full Text

155. Wootz H, Weber E, Korhonen L, et al:: Altered distribution and levels of cathepsinD and cystatins in amyotrophic lateral sclerosis transgenic mice: possible roles in motor neuron survival. Neuroscience. 2006; 143(2): 419-30. PubMed Abstract | Publisher Full Text

156. Kikuchi H, Yamada T, Furuya $\mathrm{H}$, et al.: Involvement of cathepsin $\mathrm{B}$ in the motor neuron degeneration of amyotrophic lateral sclerosis. Acta Neuropathol. 2003 105(5): 462-8. PubMed Abstract | Publisher Full Text

157. Lee S, Sato Y, Nixon RA: Lysosomal proteolysis inhibition selectively disrupts axonal transport of degradative organelles and causes an Alzheimer's-like axonal dystrophy. J Neurosci. 2011; 31(21): 7817-30. PubMed Abstract | Publisher Full Text | Free Full Text

158. Bryson JB, Hobbs C, Parsons MJ, et al.: Amyloid precursor protein (APP) contributes to pathology in the SOD1(G93A) mouse model of amyotrophic lateral sclerosis. Hum Mol Genet. 2012; 21(17): 3871-82. PubMed Abstract | Publisher Full Text

159. Guo Y, Li C, Wu D, et al:: Ultrastructural diversity of inclusions and aggregations in the lumbar spinal cord of SOD1-G93A transgenic mice. Brain Res. 2010; 1353: 234-244. PubMed Abstract | Publisher Full Text

160. Xiao S, McLean J, Robertson J: Neuronal intermediate filaments and ALS: A new look at an old question. Biochim Biophys Acta. 2006; 1762(11-12): 1001-1012. PubMed Abstract | Publisher Full Text

161. Letournel F, Bocquet A, Dubas F, et al.: Stable tubule only polypeptides (STOP) proteins co-aggregate with spheroid neurofilaments in amyotrophic lateral sclerosis. J Neuropathol Exp Neurol. 2003; 62(12): 1211-9. PubMed Abstract

162. McHolm GB, Aguilar MJ, Norris FH: Lipofuscin in amyotrophic lateral sclerosis. Arch Neurol. 1984; 41(11): 1187-8. PubMed Abstract | Publisher Full Text

163. Yang EJ, Choi SM: $\boldsymbol{\alpha}$-Synuclein Modification in an ALS Animal Model. Evid Based Complement Alternat Med. 2013; 2013: 259381. PubMed Abstract | Publisher Full Text | Free Full Text

164. Crabtree $\mathrm{D}$, Dodson $\mathrm{M}$, Ouyang $\mathrm{X}$, et al.: Over-expression of an inactive mutant cathepsin $D$ increases endogenous alpha-synuclein and cathepsin $B$ activity in SH-SY5Y cells. J Neurochem. 2014; 128(6): 950-61. PubMed Abstract | Publisher Full Text | Free Full Text

165. Asai M, Yagishita S, Iwata N et al: An alternative metabolic pathway of amyloid precursor protein C-terminal fragments via cathepsin $\mathrm{B}$ in a human neuroglioma model. FASEB J. 2011; 25(10): 3720-30. PubMed Abstract | Publisher Full Text

166. Nakano I, Shibata T, Uesaka Y: On the possibility of autolysosomal processing of skein-like inclusions. Electron microscopic observation in a case of amyotrophic lateral sclerosis. J Neurol Sci. 1993; 120(1): 54-9. PubMed Abstract | Publisher Full Text

167. Korolchuk VI, Menzies FM, Rubinsztein DC: Mechanisms of cross-talk between the ubiquitin-proteasome and autophagy-lysosome systems. FEBS Lett. 2010; 584(7): 1393-1398.

PubMed Abstract | Publisher Full Text

168. Sonnino S, Chigorno V: Ganglioside molecular species containing C18- and C20-sphingosine in mammalian nervous tissues and neuronal cell cultures.
Biochim Biophys Acta. 2000; 1469(2): 63-77.

PubMed Abstract | Publisher Full Text

169. Matsumoto A, Yoshino H, Yuki N, et al:: Ganglioside characterization of cell line displaying motor neuron-like phenotype: GM2 as a possible major ganglioside in motor neurons. $J$ Neurol Sci. 1995; 131(2): 111-8. PubMed Abstract | Publisher Full Text

170. Johnson WG: Motor neuron diseases resulting from hexosaminidase deficiency. Semin Neurol. 1993; 13(4): 369-74. PubMed Abstract | Publisher Full Text

171. Johnson WG: Hexosaminidase deficiency: a cause of recessively inherited motor neuron diseases. Adv Neurol. 1982; 36: 159-64. PubMed Abstract

172. Banerjee $\mathrm{P}$, Siciliano L, Oliveri $\mathrm{D}$, et al:: Molecular basis of an adult form of beta-hexosaminidase $\mathrm{B}$ deficiency with motor neuron disease. Biochem Biophys Res Commun. 1991; 181(1): 108-15. PubMed Abstract | Publisher Full Text

173. Dawson G, Stefansson K: Gangliosides of human spinal cord: aberrant composition of cords from patients with amyotrophic lateral sclerosis. J Neurosci Res. 1984; 12(2-3): 213-20. PubMed Abstract | Publisher Full Text

174. Rapport MM, Donnenfeld H, Brunner W, et al.: Ganglioside patterns in amyotrophic lateral sclerosis brain regions. Ann Neurol. 1985; 18(1): 60-67. PubMed Abstract | Publisher Full Text

175. Modi P, Sadasivudu B, Lakshminarayana U, et al.: Functional relationship between ammonia and gangliosides in brain. Neurochem Res. 1994; 19(3): 353-8.

PubMed Abstract | Publisher Full Tex

176. Perez LF, Casal JA, Rojas $\mathrm{P}$, et al.: Relationship between plasma ammonia concentration and $\beta$ - $\mathrm{N}$-acetylhexosaminidase isoenzyme activities in liver cirrhosis. Clin Chem Lab Med. 2000; 38(12): 1237-41. PubMed Abstract | Publisher Full Text

177. Segers K, Kadhim H, Colson C, et al.: Adult polyglucosan body disease masquerading as "ALS with dementia of the Alzheimer type": an exceptiona phenotype in a rare pathology. Alzheimer Dis Assoc Disord. 2012; 26(1): 96-9 PubMed Abstract | Publisher Full Text

178. Robitaille $\mathrm{Y}$, Carpenter S, Karpati G, et al.: A distinct form of adult polyglucosan body disease with massive involvement of central and peripheral neuronal processes and astrocytes: a report of four cases and a review of the occurrence of polyglucosan bodies in other conditions such as Lafora's disease and normal ageing. Brain. 1980; 103(2): 315-36. PubMed Abstract | Publisher Full Text

179. Atanassov CL, Muller CD, Sarhan S, et al:: Effect of ammonia on endocytosis, cytokine production and lysosomal enzyme activity of a microglial cell line. Res Immunol. 1994; 145(4): 277-88. PubMed Abstract | Publisher Full Tex

180. McDonald TD, Faust PL, Bruno $C$, et al.: Polyglucosan body disease simulating amyotrophic lateral sclerosis. Neurology. 1993; 43(4): 785-90. PubMed Abstract | Publisher Full Text

181. Sun $\mathrm{KH}$, de Pablo $\mathrm{Y}$, Vincent $F$, et al.: Deregulated Cdk5 promotes oxidative stress and mitochondrial dysfunction. $J$ Neurochem. 2008; 107(1): 265-78. PubMed Abstract | Publisher Full Text

182. Nguyen MD, Boudreau M, Kriz J, et al:: Cell cycle regulators in the neuronal death pathway of amyotrophic lateral sclerosis caused by mutant superoxide dismutase 1. J Neurosci. 2003; 23(6): 2131-40. PubMed Abstract

183. Ralay Ranaivo $\mathrm{H}$, Hodge $\mathrm{JN}$, Choi $\mathrm{N}$, et al:: Albumin induces upregulation of matrix metalloproteinase-9 in astrocytes via MAPK and reactive oxygen species-dependent pathways. J Neuroinflammation. 2012; 9: 68. PubMed Abstract | Publisher Full Text | Free Full Text

184. Lukaszewicz-Zajac M, Mroczko B, Slowik A: Matrix metalloproteinases (MMPs) and their tissue inhibitors (TIMPs) in amyotrophic lateral sclerosis (ALS) J Neural Transm. 2014; 121(11): 1387-97. PubMed Abstract | Publisher Full Text | Free Full Text

185. Kaplan A, Spiller KJ, Towne C, et al:: Neuronal matrix metalloproteinase-9 is a determinant of selective neurodegeneration. Neuron. 2014; 81(2): 333-48. PubMed Abstract | Publisher Full Text

186. Skowronska M, Zielińska M, Wójcik-Stanaszek L, et al:: Ammonia increases paracellular permeability of rat brain endothelial cells by a mechanism encompassing oxidative/nitrosative stress and activation of matrix metalloproteinases. J Neurochem. 2012; 121(1): 125-34. PubMed Abstract | Publisher Full Text | Free Full Text

187. Reszka AA, Seger R, Diltz CD, et al.: Association of mitogen-activated protein kinase with the microtubule cytoskeleton. Proc Natl Acad Sci U S A 1995; 92(19): 8881-8885.

PubMed Abstract | Free Full Text

188. Li JJ, Ji R, Shi YQ, et al.: Changes in expression of the chloride homeostasisregulating genes, $\mathrm{KCC} 2$ and $\mathrm{NKCC} 1$, in the blood of cirrhotic patients with hepatic encephalopathy. Exp Ther Med. 2012; 4(6): 1075-1080. PubMed Abstract | Publisher Full Text | Free Full Text

189. Hübner CA, Stein V, Hermans-Borgmeyer I, et al.: Disruption of KCC2 reveals an essential role of $\mathrm{K}-\mathrm{Cl}$ cotransport already in early synaptic inhibition. Neuron. 2001; 30(2): 515-524. PubMed Abstract | Publisher Full Text 
190. Fuchs A, Ringer C, Bilkei-Gorzo A, et al.: Downregulation of the potassium chloride cotransporter KCC2 in vulnerable motoneurons in the SOD1-G93A mouse model of amyotrophic lateral sclerosis. J Neuropathol Exp Neurol. 2010; 69(10): 1057-70.

PubMed Abstract | Publisher Full Text

191. Ramirez-Jarquin UN, Lazo-Gómez R, Tovar-Y-Romo LB, et al.: Spinal inhibitory circuits and their role in motor neuron degeneration. Neuropharmacology. 2014; 82: $101-7$.

PubMed Abstract | Publisher Full Text

192. Jayakumar AR, Panickar KS, Murthy ChR, et al.: Oxidative stress and mitogenactivated protein kinase phosphorylation mediate ammonia-induced cell swelling and glutamate uptake inhibition in cultured astrocytes. $J$ Neurosci. 2006; 26(18): 4774-84.

PubMed Abstract | Publisher Full Text

193. Zhou BG, Norenberg MD: Ammonia downregulates GLAST mRNA glutamate transporter in rat astrocyte cultures. Neurosci Lett. 1999; 276(3): 145-8. PubMed Abstract | Publisher Full Text

194. Howland DS, Liu J, She Y, et al.: Focal loss of the glutamate transporter EAAT2 in a transgenic rat model of SOD1 mutant-mediated amyotrophic lateral sclerosis (ALS). Proc Natl Acad Sci U S A. 2002; 99(3): 1604-9. PubMed Abstract | Publisher Full Text | Free Full Text

195. Heath PR, Shaw PJ: Update on the glutamatergic neurotransmitter system and the role of excitotoxicity in amyotrophic lateral sclerosis. Muscle Nerve. 2002; 26(4): 438-58.

PubMed Abstract | Publisher Full Text

196. Dunlop J, Beal Mcllvain $\mathrm{H}$, She $\mathrm{Y}$, et al.: Impaired spinal cord glutamate transport capacity and reduced sensitivity to riluzole in a transgenic superoxide dismutase mutant rat model of amyotrophic lateral sclerosis. J Neurosci. 2003; 23(5): 1688-96.

PubMed Abstract

197. Felipo V, Butterworth RF: Neurobiology of ammonia. Prog Neurobiol. 2002; 67(4): 259-79.

PubMed Abstract | Publisher Full Text

198. Reinehr R, Görg B, Becker S, et al:: Hypoosmotic swelling and ammonia increase oxidative stress by NADPH oxidase in cultured astrocytes and vital brain slices. Glia. 2007; 55(7): 758-71. PubMed Abstract | Publisher Full Text

199. Jayakumar AR, Tong XY, Curtis KM, et al.: Increased toll-like receptor 4 in cerebral endothelial cells contributes to the astrocyte swelling and brain edema in acute hepatic encephalopathy. J Neurochem. 2014; 128(6): 890-903. PubMed Abstract | Publisher Full Text | Free Full Text

200. Rodrigo R, Cauli O, Gomez-Pinedo U, et al.: Hyperammonemia induces neuroinflammation that contributes to cognitive impairment in rats with hepatic encephalopathy. Gastroenterology. 2010; 139(2): 675-84. PubMed Abstract | Publisher Full Text

201. Guillemin GJ, Meininger V, Brew BJ: Implications for the kynurenine pathway and quinolinic acid in amyotrophic lateral sclerosis. Neurodegener Dis. 2005; 2(3-4): 166-76.

PubMed Abstract | Publisher Full Text

202. Marrali G, Casale F, Salamone $P$, et al:: NADPH oxidase (NOX2) activity is a modifier of survival in ALS. J Neurol. 2014; 261(11): 2178-83. PubMed Abstract | Publisher Full Text

203. Casula M, Iyer AM, Spliet WG, et al.: Toll-like receptor signaling in amyotrophic lateral sclerosis spinal cord tissue. Neuroscience. 2011; 179: 233-43. PubMed Abstract | Publisher Full Text

204. Evans MC, Couch Y, Sibson N, et al.: Inflammation and neurovascular changes in amyotrophic lateral sclerosis. Mol Cell Neurosci. 2013; 53: 34-41. PubMed Abstract | Publisher Full Text

205. Appel SH, Beers D, Siklos L, et al.: Calcium: the Darth Vader of ALS. Amyotroph Lateral Scler Other Motor Neuron Disord. 2001; 2(Suppl 1): S47-54. PubMed Abstract | Publisher Full Text

206. Ince $\mathrm{P}$, Stout $\mathrm{N}$, Shaw $\mathrm{P}$, et al.: Parvalbumin and calbindin D-28k in the human motor system and in motor neuron disease. Neuropathol Appl Neurobiol. 1993; 19(4): 291-9.

PubMed Abstract | Publisher Full Text

207. Copray JC, Liem RS, Kernell D: Calreticulin expression in spinal motoneurons of the rat. J Chem Neuroanat. 1996; 11(1): 57-65. PubMed Abstract | Publisher Full Tex

208. Bernard-Marissal N, Sunyach C, Marissal T, et al.: Calreticulin levels determine onset of early muscle denervation by fast motoneurons of ALS model mice. Neurobiol Dis. 2015; 73: 130-6.

PubMed Abstract | Publisher Full Text

209. Bernard-Marissal N, Moumen A, Sunyach C, et al:: Reduced calreticulin levels link endoplasmic reticulum stress and Fas-triggered cell death in motoneurons vulnerable to ALS. J Neurosci. 2012; 32(14): 4901-12. PubMed Abstract | Publisher Full Text

210. Montague K, Malik B, Gray AL, et al.: Endoplasmic reticulum stress in spinal and bulbar muscular atrophy: a potential target for therapy. Brain. 2014; 137(Pt 7): 1894-906.

PubMed Abstract | Publisher Full Text | Free Full Text

211. Drake ME Jr: The association of motor neuron disease and Alzheimer-type dementia. Am J Med Sci. 1984; 287(3): 26-7. PubMed Abstract | Publisher Full Text

212. Crugnola $\mathrm{V}$, Lamperti $\mathrm{C}$, Lucchini $\mathrm{V}$, et al.: Mitochondrial respiratory chain dysfunction in muscle from patients with amyotrophic lateral sclerosis. Arch Neurol. 2010; 67(7): 849-54.

PubMed Abstract | Publisher Full Text

213. Menzies FM, Ince PG, Shaw PJ: Mitochondrial involvement in amyotrophic lateral sclerosis. Neurochem Int. 2002; 40(6): 543-51. PubMed Abstract | Publisher Full Text

214. Carr PA, Yamamoto T, Karmy G, et al.: Analysis of parvalbumin and calbindin D28k-immunoreactive neurons in dorsal root ganglia of rat in relation to their cytochrome oxidase and carbonic anhydrase content. Neuroscience. 1989; 33(2): 363-71.

PubMed Abstract | Publisher Full Text

215. Linnebank $\mathrm{M}$, Lutz $\mathrm{H}$, Jarre $\mathrm{E}$, et al.: Binding of copper is a mechanism of homocysteine toxicity leading to COX deficiency and apoptosis in primary neurons, PC12 and SHSY-5Y cells. Neurobiol Dis. 2006; 23(3): 725-30. PubMed Abstract | Publisher Full Text

216. Patel SP, Gamboa JL, McMullen CA, et al.: Lower respiratory capacity in extraocular muscle mitochondria: evidence for intrinsic differences in mitochondrial composition and function. Invest Ophthalmol Vis Sci. 2009; 50(1): 180-186

PubMed Abstract | Publisher Full Text | Free Full Text

217. Andrade FH, McMullen CA, Rumbaut RE: Mitochondria are fast $\mathrm{Ca}^{2+}$ sinks in rat extraocular muscles: a novel regulatory influence on contractile function and metabolism. Invest Ophthalmol Vis Sci. 2005; 46(12): 4541-7. PubMed Abstract | Publisher Full Text

218. Beauchemin AM, Gottlieb B, Beitel LK, et al: Cytochrome $\mathbf{c}$ oxidase subunit Vb interacts with human androgen receptor: a potential mechanism for neurotoxicity in spinobulbar muscular atrophy. Brain Res Bull. 2001; 56(3-4): 285-97. PubMed Abstract | Publisher Full Text

219. Comi GP, Bordoni A, Salani S, et al.: Cytochrome $\mathrm{c}$ oxidase subunit I microdeletion in a patient with motor neuron disease. Ann Neurol. 1998; 43(1): $110-6$.

PubMed Abstract | Publisher Full Text

220. Rygiel KA, Grady JP, Turnbull DM: Respiratory chain deficiency in aged spinal motor neurons. Neurobiol Aging. 2014; 35(10): 2230-2238. PubMed Abstract | Publisher Full Text | Free Full Text

221. Sullivan PG, Rabchevsky AG, Keller JN, et al.: Intrinsic differences in brain and spinal cord mitochondria: Implication for therapeutic interventions. J Comp Neurol. 2004; 474(4): 524-34.

PubMed Abstract | Publisher Full Text

222. Turner C, Parekh B, Walton C, et al.: An exploratory comparative study of volatile compounds in exhaled breath and emitted by skin using selected ion flow tube mass spectrometry. Rapid Commun Mass Spectrom. 2008; 22(4): ion flow

PubMed Abstract | Publisher Full Text

223. Wright G, Noiret L, Olde Damink SW, et al.: Interorgan ammonia metabolism in liver failure: the basis of current and future therapies. Liver Int. 2011; 31(2): $163-75$.

PubMed Abstract | Publisher Full Text

224. Diaz-Herrero MM, del Campo JA, Carbonero-Aguilar P, et al.: THDP17 decreases ammonia production through glutaminase inhibition. A new drug for hepatic encephalopathy therapy. PLoS One. 2014; 9(10): e109787. PubMed Abstract | Publisher Full Text | Free Full Text

225. Kristiansen RG, Rose CF, Fuskevåg OM, et al.: L-Ornithine phenylacetate reduces ammonia in pigs with acute liver failure through phenylacetylglycine formation: a novel ammonia-lowering pathway. Am J Physiol Gastrointest Liver Physiol. 2014; 307(10): G1024-31. PubMed Abstract | Publisher Full Text

226. Ikarashi N, Fukazawa Y, Toda T, et al.: Effect of Conclevan on endurance capacity in mice. Biol Pharm Bull. 2012; 35(2): 231-8. PubMed Abstract | Publisher Full Text

227. Matthys D, Calders $P$, Pannier JL: Inhaled salbutamol decreases blood ammonia levels during exercise in normal subjects. Eur J Appl Physiol Occup Physiol. 1998; 79(1): 110-3.

PubMed Abstract | Publisher Full Text

228. Gruzman A, Shamni O, Ben Yakir M, et al.: Novel D-xylose derivatives stimulate muscle glucose uptake by activating AMP-activated protein kinase alpha. J Med Chem. 2008; 51(24): 8096-108. PubMed Abstract | Publisher Full Text

229. Coelho WS, Costa KC, Sola-Penna M: Serotonin stimulates mouse skeletal muscle 6-phosphofructo-1-kinase through tyrosine-phosphorylation of the enzyme altering its intracellular localization. Mol Genet Metab. 2007; 92(4): enzyme

PubMed Abstract | Publisher Full Text

230. Rangroo Thrane V, Thrane AS, Wang F, et al:: Ammonia triggers neuronal disinhibition and seizures by impairing astrocyte potassium buffering. Nat Med. 2013; 19(12): 1643-1648.

PubMed Abstract | Publisher Full Text | Free Full Text

231. Osher E, Fattal-Valevski A, Sagie L, et al.: Pyrimethamine increases betahexosaminidase A activity in patients with Late Onset Tay Sachs. Mol Genet Metab. 2011; 102(3): 356-63.

PubMed Abstract | Publisher Full Text

232. Kiernan MC, Vucic S, Cheah BC, et al.: Amyotrophic lateral sclerosis. The Lancet. 2011; 377(9769): 942-955.

PubMed Abstract | Publisher Full Text 


\section{Open Peer Review}

\section{Current Peer Review Status:}

\section{Version 1}

Reviewer Report 12 December 2016

https://doi.org/10.5256/f1000research.6824.r18396

(C) 2016 Brady S. This is an open access peer review report distributed under the terms of the Creative Commons Attribution License, which permits unrestricted use, distribution, and reproduction in any medium, provided the original work is properly cited.

\section{Scott T Brady}

Department of Anatomy and Cell Biology, University of Illinois at Chicago, Chicago, IL, USA

ALS is a devastating disease of uncertain etiology and no effective therapies are available. As a result, there is a temptation to speculate about underlying causes in the hopes of hitting on the right answer. In this case, the author without any record of studying either ALS pathology or ammonia metabolism has proposed a novel integrative explanation in which impaired glycolytic metabolism in fast twitch skeletal muscle and liver pathology leads to chronically elevated ammonia levels that leads to altered $\mathrm{Ca}^{2+}$ binding protein homeostasis due to ER stress and impaired mitochondrial respiration. Based on this idea, the author proposes that ammonia removal therapies would be effective treatments for ALS.

The first requirement of any disease model is that it be consistent with known facts about the disease. Unfortunately, this model fails immediately on two counts. First, there is no evidence that interorgan ammonia levels are chronically elevated in ALS. People have been looking for plasma biomarkers for early diagnosis and none have reported elevated ammonia as a candidate in either ALS patients or animal models. The author does not cite any relevant patient studies and the one animal model cited (Bame, et al. 2014) does not find a significant correlation between ammonia levels and SOD1 G93A pathology. Similarly, liver pathology is not a hallmark of the disease. While skeletal muscle wasting is seen, this is associated with lack of activity, rather than a primary defect in glycolysis.

Second, ammonia toxicity is a well-documented condition in the brain and other tissues. While there are neurotoxic effects that include cortical atrophy, demyelination and edema (see for example Braissant, et al. 2013), none of these changes are specific to motor neurons (upper or lower) nor is there any evidence of ALS-like pathology in either patients with hyperammonemia or animal models with chronically elevated ammonia. Thus, patients with ALS show no evidence of elevated ammonia levels and patients with hyperammonemia do not have ALS-like symptoms. Curiously, both the Bame and the Braissant references are listed in the bibliography, but the conclusions are misrepresented as being consistent with the thesis.

Although the manuscript uses many buzzwords currently popular in the neurodegeneration field 
(autophagy, ER-stress, $\mathrm{Ca}^{2+}$ homeostasis, neuroinflammation, etc.), the logic that relates changes in these parameters to ammonia metabolism is never made clear. The diagrams are convoluted and have little explanatory power. In particular, Figure 2 manages to be so densely packed with symbols and labels that it is uninterpretable. In contrast, the source figure from Kiernan, et al. 2011 that was adapted is sparse and focused.

In sum, while the author has gathered a substantial bibliography, the main hypothesis is falsified by the literature and the utility of this opinion piece is therefore minimal. I would not consider this suitable for indexing in a rigorous journal.

Competing Interests: No competing interests were disclosed.

\section{I confirm that I have read this submission and believe that I have an appropriate level of expertise to state that I do not consider it to be of an acceptable scientific standard, for reasons outlined above.}

Reviewer Report 07 October 2016

https://doi.org/10.5256/f1000research.6824.r16323

(C) 2016 Saxena S. This is an open access peer review report distributed under the terms of the Creative Commons Attribution License, which permits unrestricted use, distribution, and reproduction in any medium, provided the original work is properly cited.

\section{Smita Saxena}

Institute of Cell Biology, University of Bern, Bern, Switzerland

This opinion article by Bhavin Parekh puts forward an interesting hypothesis about how ammonia neurotoxicity might influence and propagate ALS pathology. The article provides a concise introduction to the etiology of ALS with primary focus on the involvement of the skeletal muscle and liver in ALS pathogenesis. The author postulates a novel premise centering on the involvement of the liver and the distinctive occurrence of hepatic steatosis in motor neuron diseases including ALS. In depth literature is discussed for the existence of hepatic steatosis and hyperhomocysteinemia in ALS patients and other motor neuron diseases.

The opinion article then focuses on ammonia and imbalances in interorgan ammonia metabolism and further discusses how this specific ammonia imbalance induces functional deficits in organelles (Golgi, ER, lysosomes), thereby impairing critical ALS associated pathways such as macroautophagy, oxidative/nitrosative stress, neuroinflammation, and hyperexcitability of motor neurons. Lastly, the authors search for a conceptual framework to account for clinical heterogeneity observed with respect to upper and lower motor neurons in ALS and they suggest that calcium binding proteins (CaBPs) are key molecules involved in neutralizing ammonia toxicity. The author further discusses the role of calcium binding proteins such as Calreticulin in ER stress and ALS pathogenesis and proposes that ammonia neurotoxicity and the parallel loss of expression of CaBPs leads to ALS.

Overall the review is informative, well written and postulates an interesting hypothesis which 
might be of general interest to the neurodegeneration field. One of the limitations of this opinion article is that the discussion about CaBPs is restricted to Calreticulin in motor neurons, while recent studies have implicated various other ER chaperones in the ALS pathogenesis. The lack of these recent citations in the discussion concerning the involvement of ER chaperones in ALS does weaken the hypothesis. Nevertheless, this article provides an interesting area of reading and brings forward new experimental ideas for the further understanding of ALS and other neurodegenerative disorders.

Competing Interests: No competing interests were disclosed.

\section{I confirm that I have read this submission and believe that I have an appropriate level of expertise to confirm that it is of an acceptable scientific standard.}

Reviewer Report 01 September 2016

https://doi.org/10.5256/f1000research.6824.r15775

C $\mathbf{2 0 1 6}$ Krishnan V et al. This is an open access peer review report distributed under the terms of the Creative Commons Attribution License, which permits unrestricted use, distribution, and reproduction in any medium, provided the original work is properly cited.

\section{Viswanathan Krishnan}

Department of Medical Pathology \& Laboratory Medicine, University of California Davis School of Medicine, Davis, CA, USA

Joy Goto

California State University, Fresno, CA, USA

This Opinion Article introduces an interesting hypothesis connecting ammonia with ALS. The article initially begins with a discussion about the variety of etiologies of ALS and how their disparate onset and pathology is an unexplained area in the field. His main argument is the liver may be a locus for the variety of etiologies and specifically, hepatic steatosis is a unique link to motor neuron diseases, including ALS.

This Opinion Article is replete with references supporting each of the statements from skeletal muscle to the various metabolic pathways (e.g. glycolysis and glycogen metabolism), to the deficits in vital organelles (e.g. lysosomes and Golgi). The latter part of the review introduces the role of calcium binding proteins and how ammonia dyshomeostasis contributes to neurodegeneration.

The only shortcoming is the discussion on the mechanism of ammonia which mainly focuses on the in vitro application and exposure to ammonia; no chemical mechanisms following ammonia's path of chemical reaction using labeled material is cited. While it is not the role of the Opinion Article to present these types of experiments. The lack of these cited references does weaken the hypothesis of ammonia's connection to ALS. However, this article provides an interesting area of reading that may open new avenues of experimentation for researchers that are focused on understanding the connection between ammonia and not only ALS, but other diseases such as HD 
and PD.

Competing Interests: No competing interests were disclosed.

We confirm that we have read this submission and believe that we have an appropriate level of expertise to confirm that it is of an acceptable scientific standard.

Author Response 24 Feb 2018

Bhavin Parekh, University of Sheffield, Sheffield, UK

The hypothesis that ammonia plays a critical role in ALS is further bolstered by this recently study: http://www.manchester.ac.uk/discover/news/major-cause-of-dementia-discovered/.

Competing Interests: No competing interests were disclosed.

The benefits of publishing with F1000Research:

- Your article is published within days, with no editorial bias

- You can publish traditional articles, null/negative results, case reports, data notes and more

- The peer review process is transparent and collaborative

- Your article is indexed in PubMed after passing peer review

- Dedicated customer support at every stage

For pre-submission enquiries, contact research@f1000.com 